\title{
Intermetallic Phases Examination in Cast AlSi5Cu1Mg and AlCu4Ni2Mg2 Aluminium Alloys in As-Cast and T6 Condition
}

\author{
Grażyna Mrówka-Nowotnik \\ Rzeszów University of Technology, Department of Materials Science \\ Poland
}

\section{Introduction}

Cast $\mathrm{Al}-\mathrm{Si}-\mathrm{Cu}-\mathrm{Mg}$ and $\mathrm{Al}-\mathrm{Cu}-\mathrm{Ni}-\mathrm{Mg}$ alloys have a widespread application, especially in the marine structures, automotive and aircraft industry due to their excellent properties. The main alloying elements $-\mathrm{Si}, \mathrm{Cu}, \mathrm{Mg}$ and $\mathrm{Ni}$, partly dissolve in the primary $\alpha$-Al matrix, and to some extent present in the form of intermetallic phases. A range of different intermetallic phases may form during solidification, depending upon the overall alloy composition and crystallization condition. Their relative volume fraction, chemical composition and morphology exert significant influence on a technological properties of the alloys (MrówkaNowotnik G., at al., 2005; Zajac S., at al., 2002; Warmuzek M., at al. 2003). Therefore the examination of microstructure of aluminium and its alloys is one of the principal means to evaluate the evolution of phases in the materials and final products in order to determine the effect of chemical composition, fabrication, heat treatments and deformation process on the final mechanical properties, and last but not least, to evaluate the effects of new procedures of their fabrication and analyze the cause of failures (Christian, 1995; Hatch, 1984; Karabay et al., 2004). Development of morphological structures that become apparent with the examination of aluminium alloys microstructure arise simultaneously with the freezing, homogenization, preheat, hot or cold reduction, anneling, solution and precipitation heat treatment of the aluminium alloys. Therefore, the identification of intermetallic phases in aluminium alloys is very important part of complex investigation. These phases are the consequence of equilibrium and nonequilibrium reactions occurred during casting af aluminium alloy. It worth to mention that good interpretation of microstructure relies on heaving a complete history of the samples for analysis.

Commercial aluminium alloys contains a number of second-phase particles, some of which are present because of deliberate alloying additions and others arising from common impurity elements and their interactions. Coarse intermetallic particles are formed during solidification - in the interdendric regions, or whilst the alloy is at a relatively high temperature in the solid state, for example, during homogenization, solution treatment or recrystallization (Cabibbo at al., 2003; Gupta at al., 2001; Gustafsson at al., 1998; Griger at al., 1996; Polmear, 1995; Zhen at al., 1998). They usually contain Fe and other alloying elements 
and/or impurities. In the aluminium alloys besides the alloying elements, transition metals such as $\mathrm{Fe}, \mathrm{Mn}$ and $\mathrm{Cr}$ are always present. Even small amount of these impurities causes the formation of a new phase component. The exact composition of an alloy and the casting condition will directly influence the amount and type of intermetallic phases (Dobrzański at al., 2007; Warmuzek at al. 2004, Zając at al., 2002). Depending on the composition, a material may contain $\mathrm{CuAl}_{2}, \mathrm{Mg}_{2} \mathrm{Si}, \mathrm{CuMgAl}_{2}$, and $\mathrm{Si}$ as well as $\mathrm{Al}(\mathrm{Fe}, \mathrm{M}) \mathrm{Si}$ particles, where $\mathrm{M}$ denotes such elements as $\mathrm{Mn}, \mathrm{V}, \mathrm{Cr}, \mathrm{Mo}, \mathrm{W}$ or $\mathrm{Cu}$. During homogenization or annealing, most of the as-cast soluble particles from the major alloying additions such as $\mathrm{Mg}$, $\mathrm{Si}$ and $\mathrm{Cu}$ dissolve in the matrix and they form intermediate-sized 0.1 to $1 \mu \mathrm{m}$ dispersoids of the AlCuMgSi type. Dispersoids can also result from the precipitation of $\mathrm{Mn}-, \mathrm{Cr}-$, or $\mathrm{Zr}-$ containing phases. A size and distribution of these various dispersoids depend on the time and temperature of the homogenization and/or annealing processes. Fine intermetallic particles $(<1 \mu \mathrm{m})$ form during artificial aging of alloys and they are more uniformly distributed than constituent particles or dispersoids. Dimensions, shape and distribution of these particles may have also important influence on the ductility of the alloys. Therefore, a systematic research is necessary regarding their formation, structure and composition. For example, the coarse particles can have a significant influence on a recrystallization process, fracture, surface and corrosion, while the dispersoids control grain size and provide stability to the metallurgical structure. Dispersoids can also have a large affect on the fracture performance and may limit strain localization during deformation. The formation of particles drains solute from the matrix and, consequently, changes the mechanical properties of the material. This is particularly relevant to the heat-treatable alloys, where depletion in $\mathrm{Cu}, \mathrm{Mg}$, and $\mathrm{Si}$ can significantly change the metastable precipitation processes and age hardenability of the material (Garcia-Hinojosa at al., 2003; Gupta at al., 2001; Sato at al., 1985). Therefore, the particle characterization is essential not only for choosing the best processing routes, but also for designing the optimized alloy composition (MrówkaNowotnik at al., 2007; Wierzbińska at al., 208, Zajac at al., 2002; Zhen at al., 1998).

The main objective of this study was to analyze a morphology and composition of the complex microstructure of intermetallic phases in AlSi5Cu1Mg and AlCu4Ni2Mg2 aluminium alloys in as-cast and T6 condition and recommend accordingly, the best experimental techniques for analysis of the intermetallic phases occurring in the aluminium alloys.

\section{Material and methodology}

The investigation was carried out on the AlCu4Ni2Mg2 and AlSi5Cu1Mg casting aluminium alloys. The chemical composition of the alloys is indicated in Table 1.

\begin{tabular}{|l|c|c|c|c|c|c|c|}
\hline Alloy & $\mathbf{C u}$ & $\mathbf{M g}$ & $\mathbf{S i}$ & $\mathbf{F e}$ & $\mathbf{N i}$ & $\mathbf{Z n}$ & $\mathbf{T i}$ \\
\hline AlSi5Cu1Mg & 1.3 & 0.5 & 5.2 & 0.2 & - & $<0.3$ & 0.18 \\
\hline AlCu4Ni2Mg2 & 4.3 & 1.5 & 0.1 & 0.1 & 2.1 & 0.3 & - \\
\hline
\end{tabular}

Table 1. Chemical composition of investigated $\mathrm{AlCu} 4 \mathrm{Ni} 2 \mathrm{Mg} 2$ and $\mathrm{AlSi} 5 \mathrm{Cu} 1 \mathrm{Mg}$ aluminium alloys, $\mathrm{Al}$ bal (wt \%)

Microstructure analysis was carried out on the as-cast and in T6 condition aluminium alloys. The alloys were subjected to T6 heat treatment: solution heat treated at $520^{\circ} \mathrm{C}$ for $5 \mathrm{~h}$ followed by water cooling and aging at $250^{\circ} \mathrm{C}$ for $5 \mathrm{~h}$ followed by air cooling. The 
microstructure of examined alloy was observed using an optical microscope on the polished sections etched in Keller solution $\left(0.5 \% \mathrm{HF}\right.$ in $\left.50 \mathrm{ml} \mathrm{H}_{2} \mathrm{O}\right)$. The observation of specimens morphology was performed on a scanning electron microscope (SEM), operating at 6-10 kV in a conventional back-scattered electron mode and a transmission electron microscopes (TEM) operated at 120,180 and $200 \mathrm{kV}$. The thin foils were prepared by the electrochemical polishing in: $260 \mathrm{ml} \mathrm{CH}_{3} \mathrm{OH}+35 \mathrm{ml}$ glycerol $+5 \mathrm{ml} \mathrm{HClO}_{4}$. The chemical composition of the intermetallics was made by energy dispersive spectroscopy (EDS) attached to the SEM.

The intermetallic particles from investigated AlCu4Ni2Mg2 and AlSi5Cu1Mg alloys in T6 condition were extracted chemically in phenol. The samples in the form of disc were cut out from the rods of $\varnothing 12 \mathrm{~mm}$ diameter. Then $\sim 0.8 \mathrm{~mm}$ thick discs were prepared by two-sided grinding to a final thickness of approximately $0.35 \mathrm{~mm}$. The isolation of phases was performed according to following procedure: $1.625 \mathrm{~g}$ of the sample to be dissolved was placed in a $300 \mathrm{ml}$ flask containing $120 \mathrm{~mm}$ of boiling phenol $\left(182^{\circ} \mathrm{C}\right)$. The process continued until the complete dissolution of the sample occurred $\sim 10 \mathrm{~min}$. The phenolic solution containing the residue was treated with $100 \mathrm{ml}$ benzyl alcohol and cooled to the room temperature. The residue was separated by centrifuging a couple of times in benzyle alcohol and then twice more in the methanol. The dried residue was refined in the mortar. After sieving of residue $\sim 0.2 \mathrm{~g}$ isolate was obtained. The intermetallic particles from the powder extract were identified by using X-ray diffraction analysis. The X-ray diffraction analysis of the powder was performed using a diffractometer - $\mathrm{Cu} \mathrm{K \alpha}$ radiation at $40 \mathrm{kV}$.

DSC measurements were performed using a calorimeter with a sample weight of approximately $80-90 \mathrm{mg}$. Temperature scans were made from room temperature $\sim 25^{\circ} \mathrm{C}$ to $800^{\circ} \mathrm{C}$ with constants heating rates of $5^{\circ} \mathrm{C}$ in a dynamic argon atmosphere. The heat effects associated with the transformation (dissolution/precipitation) reactions were obtained by subtracting a super purity Al baseline run and recorded.

\section{Results and discussion}

DSC curves obtained by heating (Fig. 1a) and cooling (Fig. 1b) as-cast specimens of the examined AlSi5Cu1Mg alloy are shown in Fig. 1. DSC curves demonstrate precisely each reactions during heating and solidification process of as-cast AlSi5Cu1Mg alloy. One can see from the figures that during cooling the reactions occurred at lower temperatures (Fig. 1b) compared to the values recorded during heating of the same alloy (Fig. 1a). Solidification process of this alloy is quite complex (Fig. 1) and starts from formation of aluminum reach $(\alpha-\mathrm{Al})$ dendrites. Additional alloying elements such as: $\mathrm{Mg}, \mathrm{Cu}$, as well as impurities: $\mathrm{Mn}$, $\mathrm{Fe}$, leads to more complex solidification reaction. Therefore, as-cast microstructure of AlSi5Cu1Mg alloy presents a mixture of intermetallic phases (Fig. 2). The solidification reactions (the exact value of temperature) obtained during DSC investigation were compared with the literature data (Bäckerud at al., 1992; Li, et al., 2004) and presented in Table 2. Results obtained in this work very well corresponding to the (Bäckerud at al., 1992; Li, et al., 2004; Dobrzański at al., 2007).

Fig. 2 shows as-cast microstructure of AlSi5Cu1Mg alloy. The analyzed microstructure contains of primary aluminium dendrites and substantial amount of different intermetallic phases constituents varied in shape, (i.e.: needle, plate-like, block or "Chinese script"), size and distribution. They are located at the grain boundaries of $\alpha-\mathrm{Al}$ and form dendritic network structure (Fig. 2). 


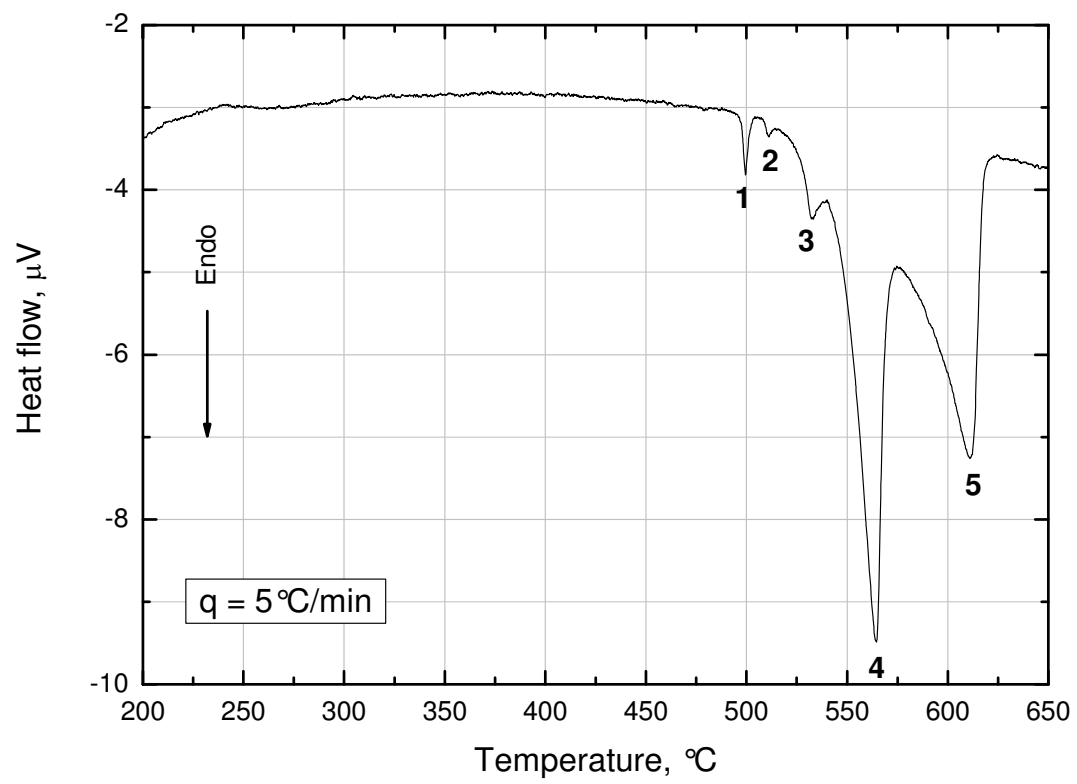

(a)

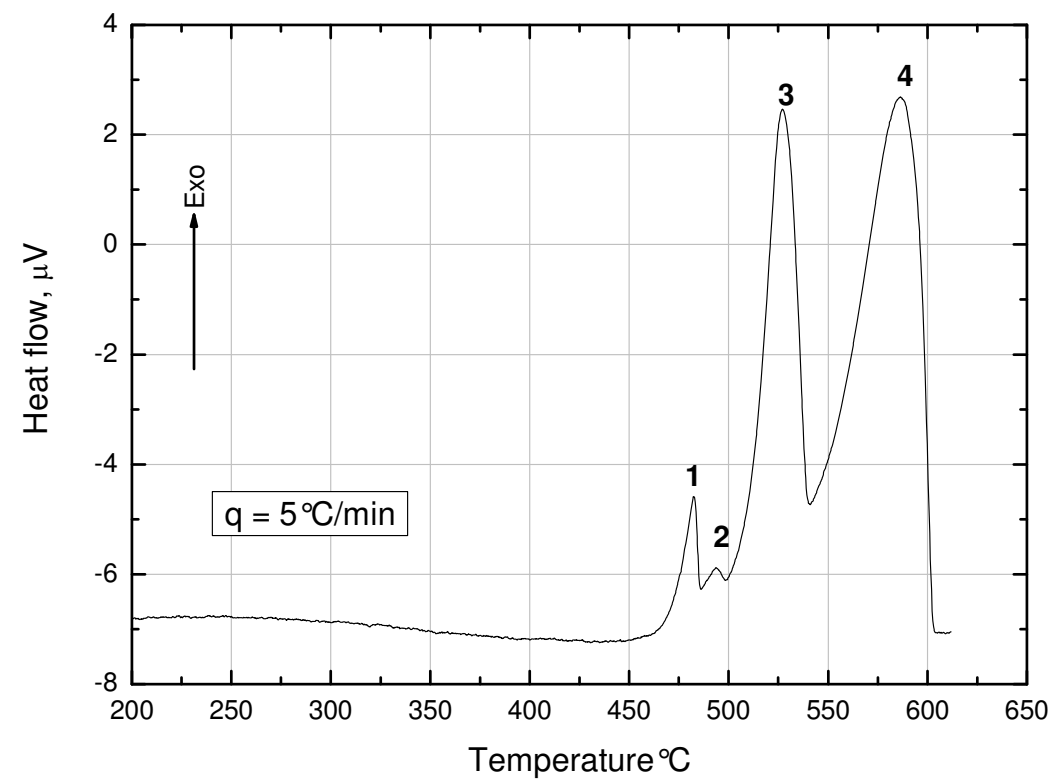

(b)

Fig. 1. DSC thermograms of as-cast specimens of AlSi5Cu1Mg alloy, obtained during a) heating and b) cooling at rate of $5^{\circ} \mathrm{C} / \mathrm{min}$ 


\begin{tabular}{|l|c|c|c|c|}
\hline Bäckerud et al. & Temp., $^{\circ} \mathbf{C}$ & $\mathbf{~ L i , ~ S a m u e l ~ e t ~ a l . ~}$ & Temp., ${ }^{\circ} \mathbf{C}$ & This work \\
\hline $\mathrm{L} \rightarrow(\mathrm{Al})$ dendrite network & 609 & $(\mathrm{Al})$ dendrite network & 610 & 610 \\
\hline $\mathrm{L} \rightarrow(\mathrm{Al})+\mathrm{Al}_{15} \mathrm{Mn}_{3} \mathrm{Si}_{2}+\left(\mathrm{Al}{ }_{5} \mathrm{FeSi}\right)$ & 590 & & & \\
\hline $\mathrm{L} \rightarrow(\mathrm{Al})+\mathrm{Si}+\mathrm{Al}_{5} \mathrm{FeSi}$ & 575 & Precipitation of eutectic $\mathrm{Si}$ & 562 & 564 \\
\hline $\mathrm{L} \rightarrow(\mathrm{Al})+\mathrm{Si}+\mathrm{AlMnFeSi}$ & 558 & $\begin{array}{c}\text { Precipitation of } \\
\mathrm{Al}_{6} \mathrm{Mg}_{3} \mathrm{FeSi}_{6}+\mathrm{Mg}_{2} \mathrm{Si}\end{array}$ & 554 & 532 \\
\hline $\mathrm{L} \rightarrow(\mathrm{Al})+\mathrm{Al}_{2} \mathrm{Cu}+\mathrm{Al}_{5} \mathrm{FeSi}$ & 525 & Precipitation of $\mathrm{Al}_{2} \mathrm{Cu}$ & 510 & 510 \\
\hline $\begin{array}{l}\mathrm{L} \rightarrow(\mathrm{Al})+\mathrm{Al}_{2} \mathrm{Cu}+\mathrm{Si}+ \\
\mathrm{Al}_{5} \mathrm{Mg} \mathrm{Cu}_{2} \mathrm{Si}_{6}\end{array}$ & 507 & $\begin{array}{c}\text { Precipitation of } \\
\mathrm{Al}_{5} \mathrm{Mg}_{8} \mathrm{Cu}_{2} \mathrm{Si}_{6}\end{array}$ & 490 & 499 \\
\hline
\end{tabular}

Table 2. Reactions occurring during the solidification of the AlSi5Cu1Mg alloy according to (Bäckerud at al., 1992; Li, Samuel et al., 2004)

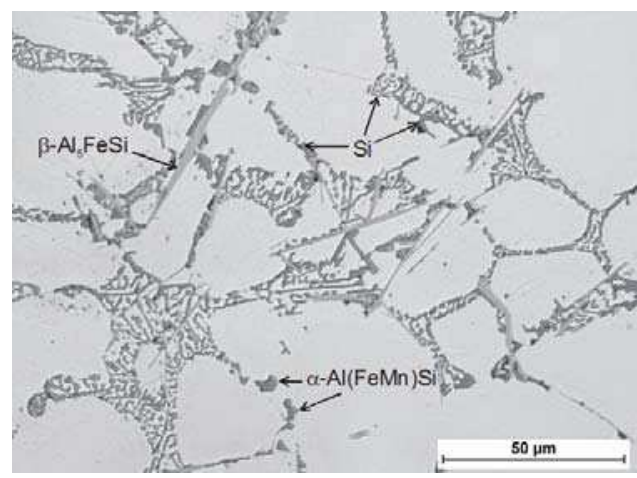

(a)

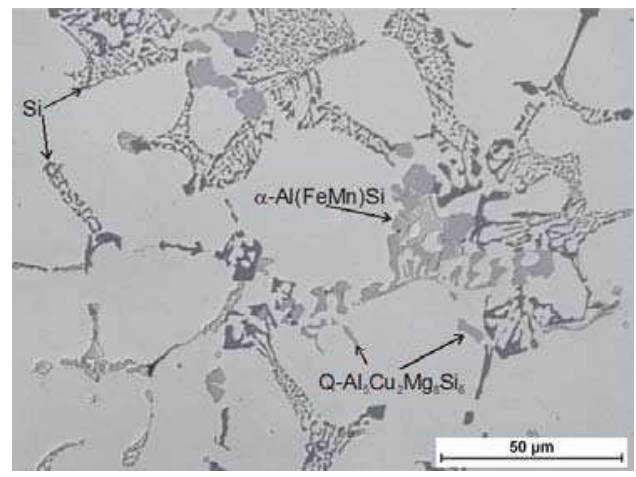

(c)

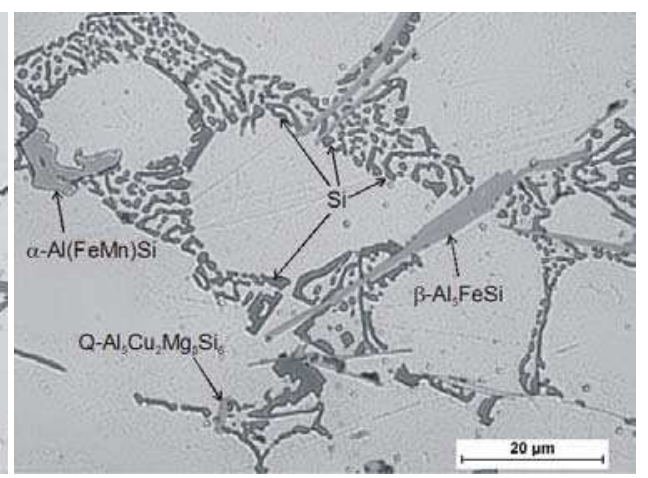

(b)

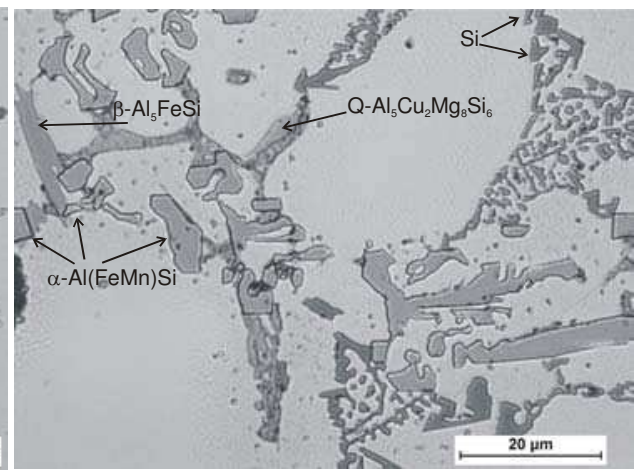

(d)

Fig. 2. Morphology of AlSi5Cu1Mg alloy in the as-cast state: $(a, c)$ unetched and $(b, d)$ etched In order to identify the intermetallic phases in the examined alloy, series of elemental maps were performed for the elements line Al-K, Mg-K, Fe-K, Si-K, Cu-K and Mn-K (Fig. 3 and 4). The maximum pixel spectrum clearly shows the presence of $\mathrm{Al}, \mathrm{Mg}, \mathrm{Fe}, \mathrm{Si}, \mathrm{Cu}$ and $\mathrm{Mn}$ in the 
scanned microstructure. In order to identify the presence of the elements in the observed phases, characteristic regions of the mapped phase with high $\mathrm{Mg}, \mathrm{Fe}, \mathrm{Si}, \mathrm{Cu}$ and $\mathrm{Mn}$ concentration were marked and their spectra evaluated (Fig. 5).
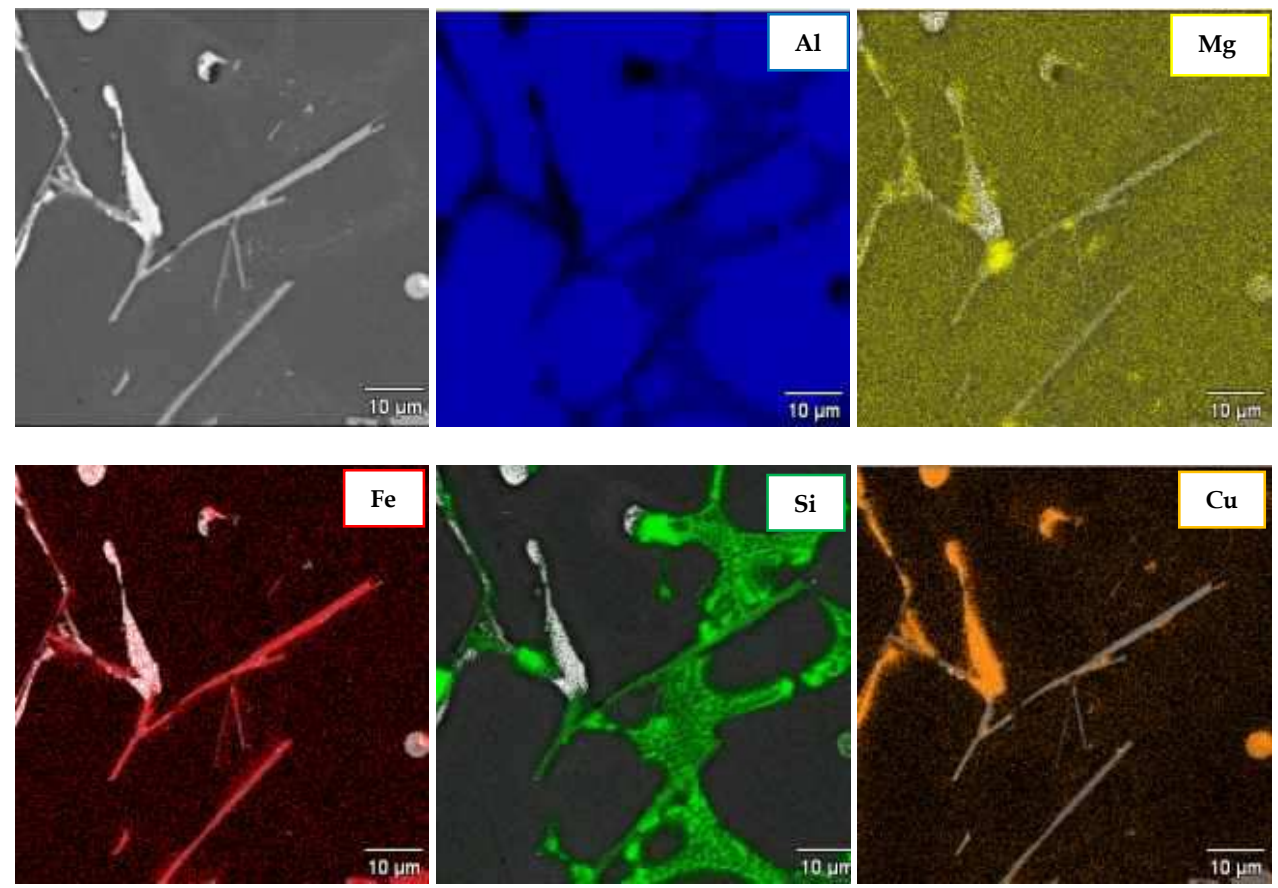

Fig. 3. SEM image of the AlSi5Cu1Mg alloy and corresponding elemental maps of: $\mathrm{Al}, \mathrm{Mg}$, $\mathrm{Fe}, \mathrm{Si}$ and $\mathrm{Cu}$

Fig. 5 shows the SEM micrographs with corresponding EDS-spectra of intermetallics observed in the as-cast AlSi5Cu1Mg alloy. The EDS analysis indicate that the oval particles are $\mathrm{Al}_{2} \mathrm{Cu}$ (Fig. 5a). Besides $\mathrm{Al}_{2} \mathrm{Cu}$ phase, another $\mathrm{Cu}$ containing phase $\mathrm{Al}_{5} \mathrm{Mg}_{8} \mathrm{Cu}_{2} \mathrm{Si}_{6}$ was observed (Fig. 4,5). In addition the Cu-containing intermetallics nucleating as dark grey rod, primary eutectic Si particles with "Chinese script" morphology were also observed. Fe has a very low solid solubility in $\mathrm{Al}$ alloy (maximum $0.05 \%$ at equilibrium) (Mondolfo, 1976), and most of $\mathrm{Fe}$ in aluminium alloys form a wide variety of Fe-containing intermetallics depending on the alloy composition and its solidification conditions (Ji et al., 2008). In the investigated as-cast AlSi5Cu1Mg alloy Fe-containing intermetallics such as light grey needle like $\beta-\mathrm{Al}_{5} \mathrm{FeSi}$ (Fig. 5a) and blockly phase consisting of $\mathrm{Al}, \mathrm{Si}, \mathrm{Mn}$ and $\mathrm{Fe}$ (Fig. 5a) were observed. On the basic of literature date (Liu Y.L. et al., 1999; Mrówka-Nowotnik et al., a,b, 2007; Wierzbińska et al., 2008) and EDS results (Fig. 5 and Tab.3) this particles were identified as $\alpha-\mathrm{Al}(\mathrm{FeMn}) \mathrm{Si}$ phase.

Fig. 5 shows SEM micrographs with corresponding EDS-spectra of intermetallics observed in as-cast $\mathrm{AlSi} 5 \mathrm{Cu} 1 \mathrm{Mg}$ alloy. The EDS spectra indicate that the oval particles are $\mathrm{Al}_{2} \mathrm{Cu}$ (Fig. 5a). Besides $\mathrm{Al}_{2} \mathrm{Cu}$ phase, another $\mathrm{Cu}$ containing phase $\mathrm{AlCuMgSi}$ is observed (Fig $5 \mathrm{~b}$ ). The results of EDS analysis are summarized in Tab. 3 versus the results obtained by earlier investigators. 

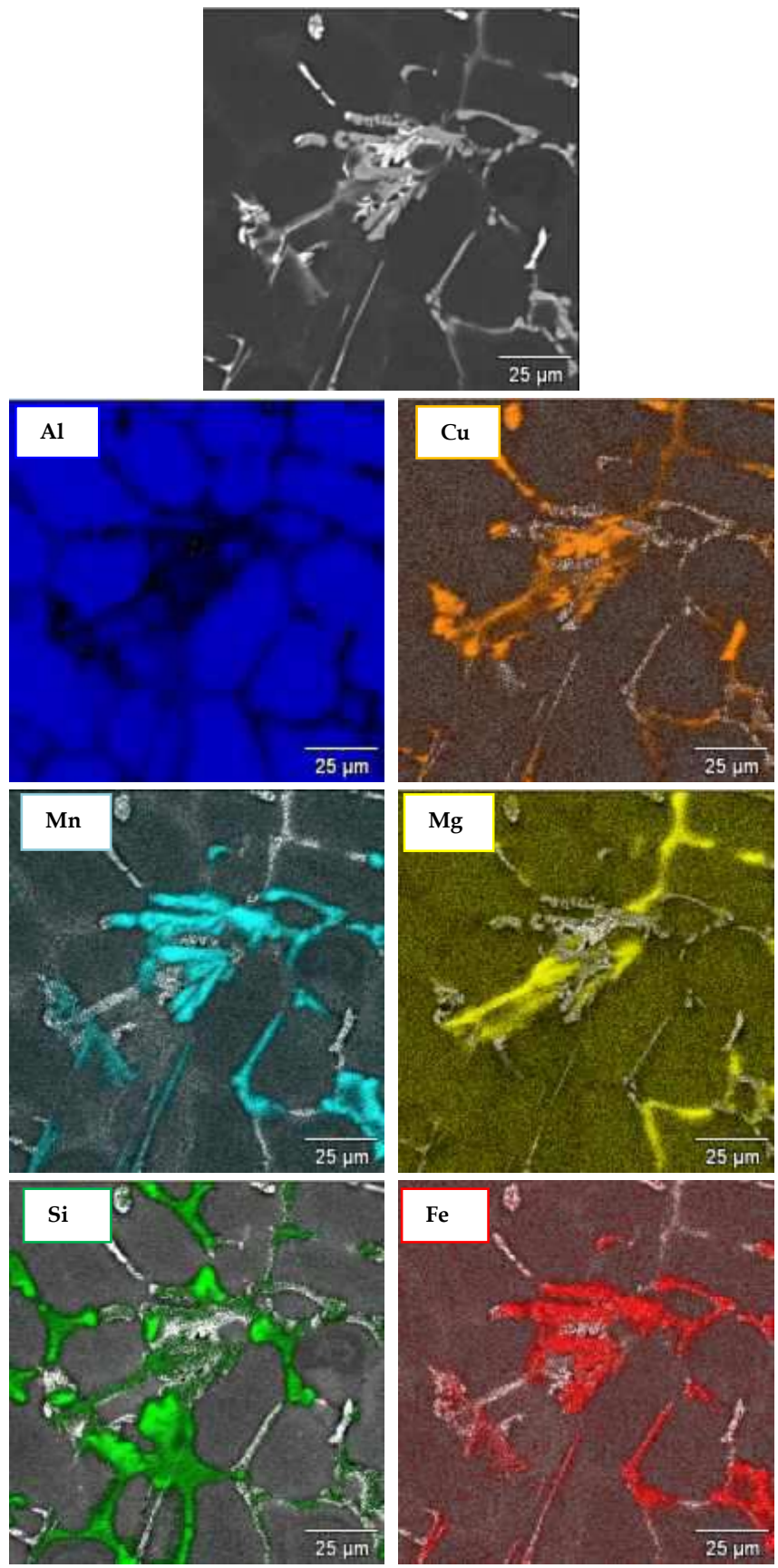

Fig. 4. SEM image of the AlSi5Cu1Mg alloy and corresponding elemental maps of: $\mathrm{Al}, \mathrm{Mn}$, $\mathrm{Mg}$, Fe, $\mathrm{Si}$ and $\mathrm{Cu}$ 
The following phases were identified in the as-cast AlSi5Cu1Mg alloy based on DSC results and microstructure - LM and SEM observations (Tab. 2 and 3, Fig. 1-5): Si, $\beta-\mathrm{Al}_{5} \mathrm{FeSi}$, $\mathrm{Al}_{5} \mathrm{Cu}_{2} \mathrm{Mg}_{8} \mathrm{Si}_{6}, \mathrm{Al}_{2} \mathrm{Cu}, \alpha-\mathrm{Al}(\mathrm{FeMn}) \mathrm{Si}$. These results can suggest, that in this alloys occur five solidification reactions (Tab. 4). The data presented in Tab. 4 shows that the solidification sequence of AlSi5Cu1Mg alloy differ only slightly from this obtained by Backerud and $\mathrm{Li}$ (Tab. 2).

\begin{tabular}{|c|c|c|c|c|c|c|c|}
\hline \multirow{2}{*}{$\begin{array}{c}\text { No. of } \\
\text { analyzed } \\
\text { particles }\end{array}$} & \multirow{2}{*}{$\begin{array}{l}\text { Suggested type } \\
\text { of phases }\end{array}$} & \multicolumn{5}{|c|}{$\begin{array}{l}\text { Chemical composition of determined } \\
\text { intermetallic phases, ( } \% \text { wt) }\end{array}$} & \multirow[t]{2}{*}{ References } \\
\hline & & Si & $\mathrm{Cu}$ & $\mathrm{Mg}$ & $\mathrm{Fe}$ & Mn & \\
\hline 20 & $\mathrm{Al}_{5} \mathrm{Cu}_{2} \mathrm{Mg}_{8} \mathrm{Si}_{6}$ & $\begin{array}{c}19.2 \\
15.2 \\
17.97\end{array}$ & $\begin{array}{r}31.1 \\
26.9 \\
27.48\end{array}$ & $\begin{array}{c}33 \\
29.22 \\
28.49\end{array}$ & & & $\begin{array}{l}\text { Ji, } 2008 \\
\text { Lodgaard, (2000) } \\
\text { This work }\end{array}$ \\
\hline 25 & $\beta-\mathrm{Al}_{5} \mathrm{FeSi}$ & $\begin{array}{c}12-15 \\
12.2 \\
14.59 \\
13-16\end{array}$ & & & $\begin{array}{c}25-30 \\
25 \\
27.75 \\
23-26\end{array}$ & & $\begin{array}{l}\text { Mondolfo, } 1976 \\
\text { Warmuzek, } 2005 \\
\text { Liu, } 1999 \\
\text { This work }\end{array}$ \\
\hline 12 & $\underset{\mathrm{Al}_{12}(\mathrm{FeMn})_{3} \mathrm{Si}}{\alpha-}$ & $\begin{array}{c}10-12 \\
5.5-6.5 \\
5-7 \\
8-12\end{array}$ & & & $\begin{array}{l}10-15 \\
5.1-28 \\
10-13 \\
11-13\end{array}$ & $\begin{array}{l}15-20 \\
14-24 \\
19-23 \\
14-20\end{array}$ & $\begin{array}{l}\text { Mondolfo, } 1976 \\
\text { Warmuzek, } 2006 \\
\text { Liu, } 1999 \\
\text { This work }\end{array}$ \\
\hline 10 & $\mathrm{Al}_{2} \mathrm{Cu}$ & & $\begin{array}{r}52.5 \\
49.51\end{array}$ & & & & $\begin{array}{l}\text { Belov, } 2005 \\
\text { This work }\end{array}$ \\
\hline 25 & $\mathrm{Si}$ & $85-95$ & & & & & This work \\
\hline
\end{tabular}

Table 3. The chemical composition of the intermetallic phases in AlSi5Cu1Mg alloy in the as-cast state
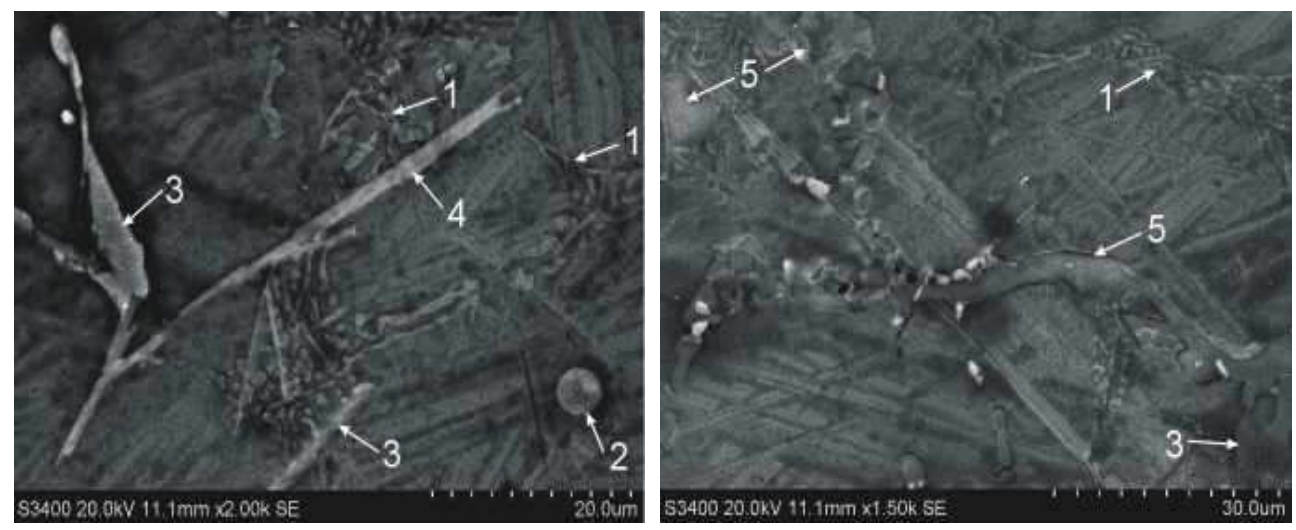

Fig. 5. a) SEM micrographs of the AlSi5Cu1Mg alloy in the as-cast state 

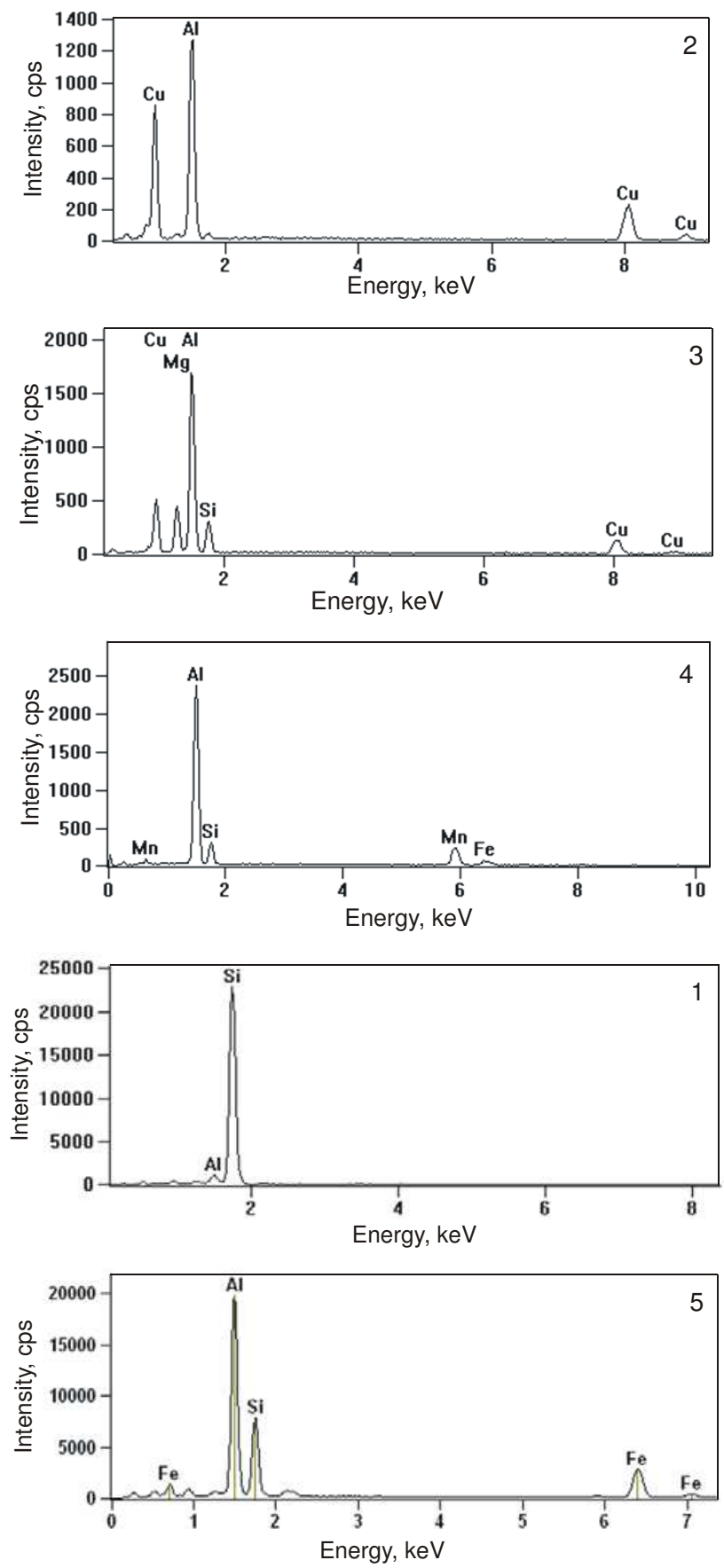

Fig. 5. b) The corresponding EDS-spectra acquired in positions indicated by the number 1-5 


\begin{tabular}{|l|c|}
\hline Reactions & Temperature, ${ }^{\circ} \mathbf{C}$ \\
\hline $\mathrm{L} \rightarrow(\mathrm{Al})$ dendrite network & 610 \\
\hline $\mathrm{L} \rightarrow(\mathrm{Al})+\mathrm{Si}+\mathrm{Al}_{5} \mathrm{FeSi}$ & 564 \\
\hline $\mathrm{L} \rightarrow(\mathrm{Al})+\mathrm{Si}+\mathrm{AlMnFeSi}$ & 532 \\
\hline $\mathrm{L} \rightarrow(\mathrm{Al})+\mathrm{Al}_{2} \mathrm{Cu}+\mathrm{Al}_{5} \mathrm{FeSi}$ & 510 \\
\hline $\mathrm{L} \rightarrow(\mathrm{Al})+\mathrm{Al}_{2} \mathrm{Cu}+\mathrm{Si}+\mathrm{Al}_{5} \mathrm{Cu}_{2} \mathrm{Mg}_{8} \mathrm{Si}_{6}$ & 499 \\
\hline
\end{tabular}

Table 4. Solidification reactions during nonequilibrium conditions in the investigated $\mathrm{AlSi} 5 \mathrm{Cu} 1 \mathrm{Mg}$ alloy, heating rate was $5^{\circ} \mathrm{C} / \mathrm{min}$

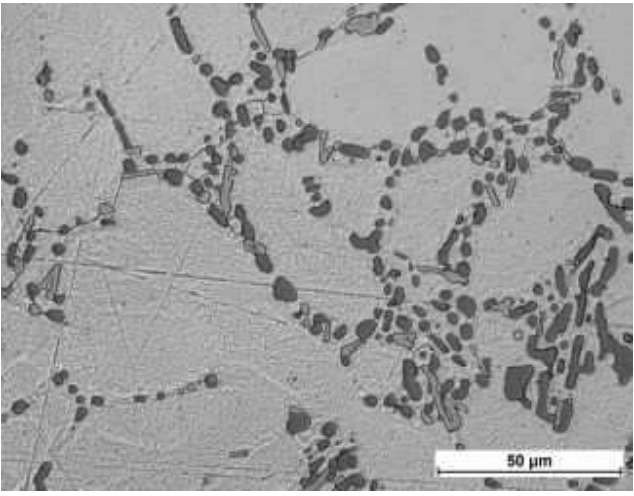

(a)

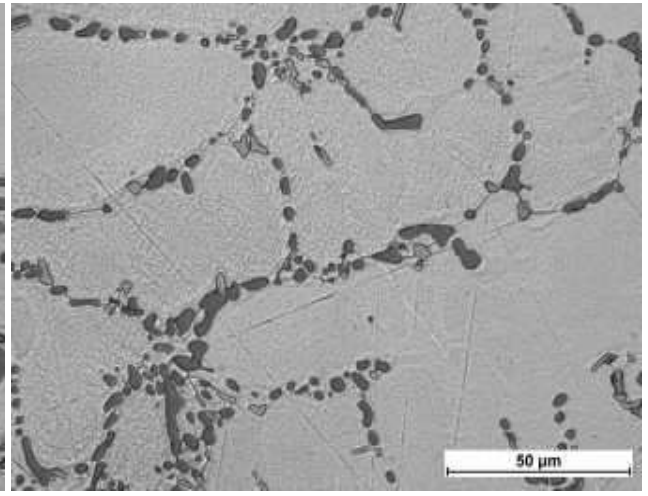

(b)

Fig. 6. The microstructure of AlSi5Cu1Mg alloy in the T6 condition (a,b)

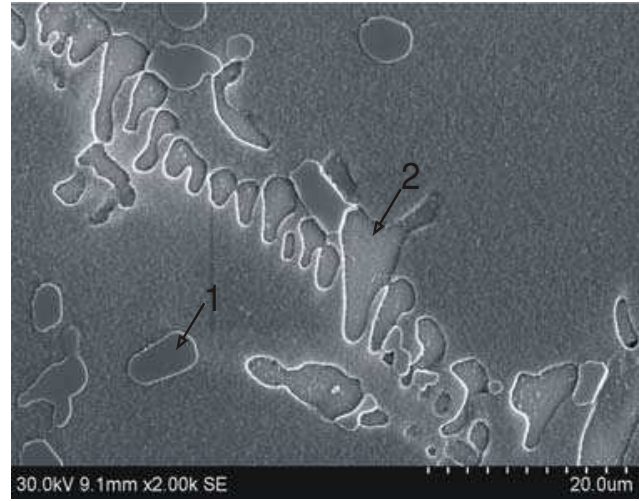

(a)
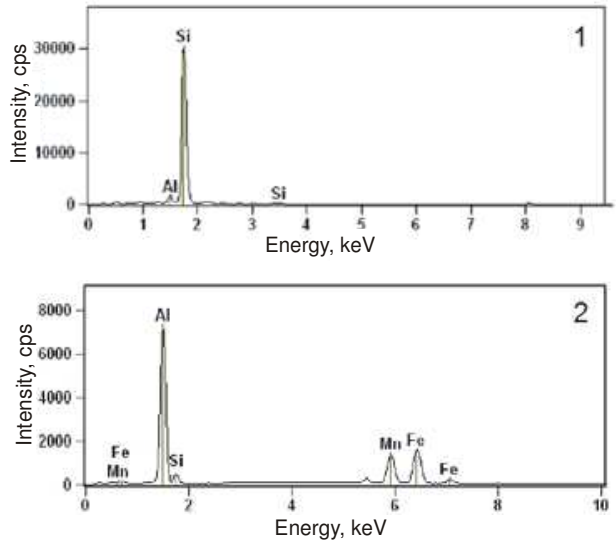

(b)

Fig. 7. a) SEM micrographs of the AlSi5Cu1Mg alloy in the T6 condition; b) The corresponding EDS-spectra acquired in the positions indicated by the number 1 and 2 
Microstructure of AlSi5Cu1Mg alloy in T6 condition is presented in Fig. 6. Analyzing the micrographs of the alloy after heat treatment at $520^{\circ} \mathrm{C}$ for $5 \mathrm{~h}$ it had been found that during solution heat treatment the morphology of primary eutectic Si changes from relatively large needle like structure to the more refined "Chinese script" and spherical in shape particles. Most of the needle like particles of $\beta-\mathrm{Al}_{5} \mathrm{FeSi}$ phase transform into spherical-like $\alpha-\mathrm{Al}(\mathrm{FeMn}) \mathrm{Si}$ (Kuijpers at al, 2002; Liu at al., 1999; Christian, 1995) as shown in Figure 6 and 7. It has been found that $\mathrm{Al}_{2} \mathrm{Cu}$ and $\mathrm{Al}_{5} \mathrm{Cu}_{2} \mathrm{Mg}_{8} \mathrm{Si}_{6}$ phases dissolve in the $\alpha-\mathrm{Al}$ matrix during solution heat treatment. The subsequent aging heat treatment at $250^{\circ} \mathrm{C}$ for 5 leads to formation form the supersaturated solid solution fine intermetallic strengthening particles of $\mathrm{Al}_{2} \mathrm{Cu}(<l \mu \mathrm{m})$.

Fig. 7 shows scanning electron micrographs and EDS analysis of particles in the investigated AlSi5Cu1Mg alloy in T6 condition. The EDS analysis performed on the phases presented in microstructure of the alloy revealed, that spherical in shape inclusions are the eutectic
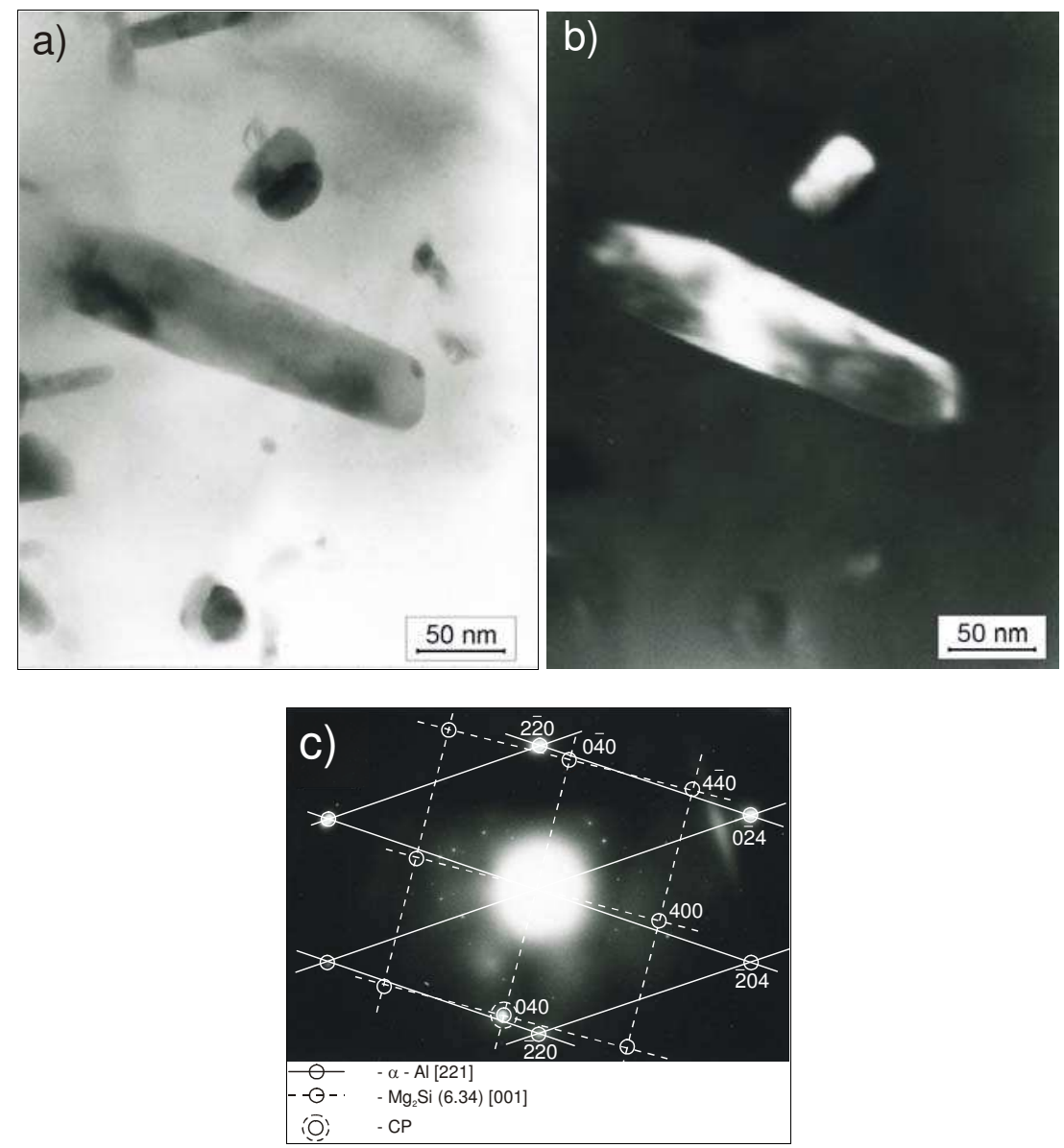

Fig. 8. TEM micrograph of AlSi5Cu1Mg alloy in T6 conditions showing the precipitate of the $\beta-\mathrm{Mg}_{2} \mathrm{Si}$ phase $(\mathrm{a}, \mathrm{b})$, and corresponding electron diffraction pattern (c) 
silicon ones, whereas the rod-like and "Chinese script" shaped, are inclusions of the phase consisting of Al, Si, Mn and Fe (Fig. 2,7 and Tab. 3).

Since it is rather difficult to produce detailed identification of intermetallic using only one method (e.g. microscopic examination) therefore XRD and TEM techniques was utilized to provide confidence in the results of phase classification based on metallographic study. The microstructure of the examined alloy $\mathrm{AlSi} 5 \mathrm{Cu} 1 \mathrm{Mg}$ in $\mathrm{T} 6$ state consists of the primary precipitates of intermetallic phases combined with the highly dispersed particles of hardening phases. The TEM micrographs and the selected area electron diffraction patterns analysis proved that the dispersed precipitates shown in Figure 8 and 9 were the precipitates of hardening phase $\beta-\mathrm{Mg}_{2} \mathrm{Si}$ (Fig. 8) and $\theta^{\prime}-\mathrm{Al}_{2} \mathrm{Cu}$ (Fig. 9).

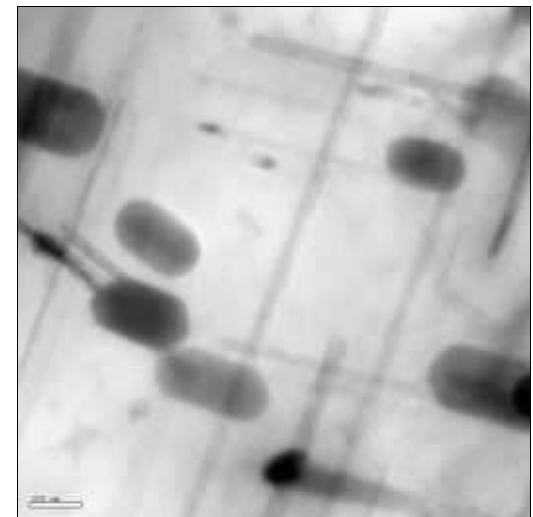

(a)

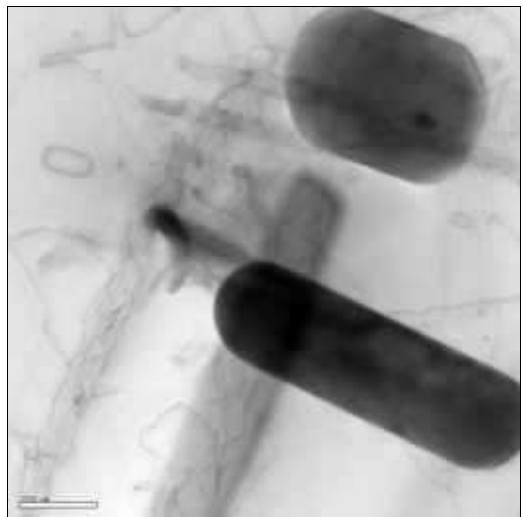

(b)

Fig. 9. Precipitation of strengthening $\beta-\mathrm{Mg}_{2} \mathrm{Si}$ i $\theta^{\prime}-\mathrm{Al}_{2} \mathrm{Cu}$ phases in $\mathrm{AlSi} 5 \mathrm{Cu} 1 \mathrm{Mg}(\mathrm{a}, \mathrm{b})-\mathrm{TEM}$

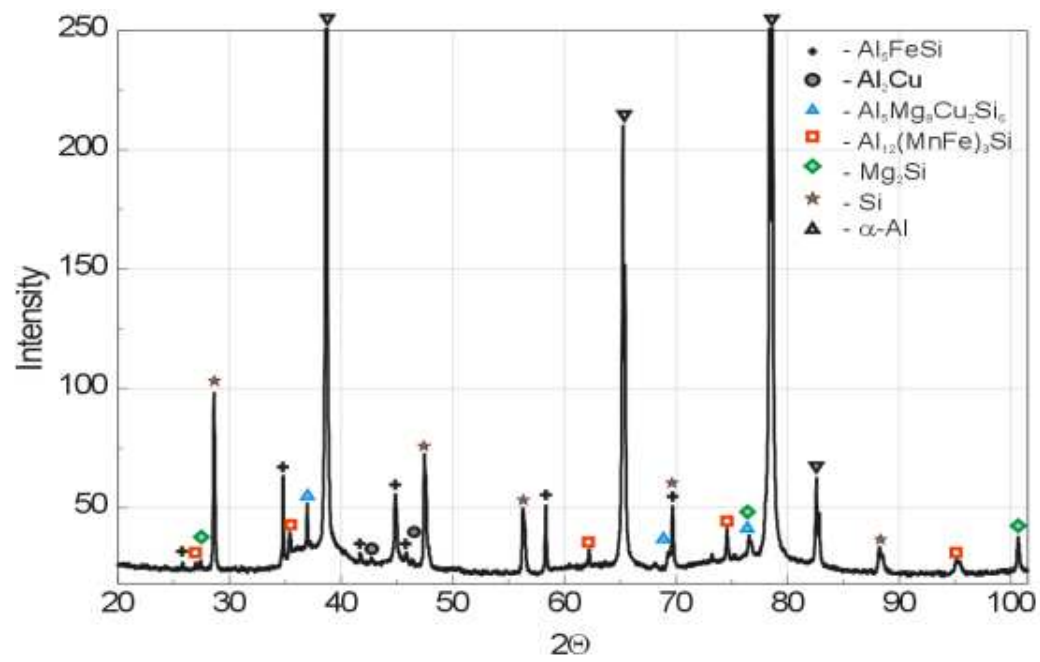

Fig. 10. X-diffraction pattern of AlSi5Cu1Mg alloy 


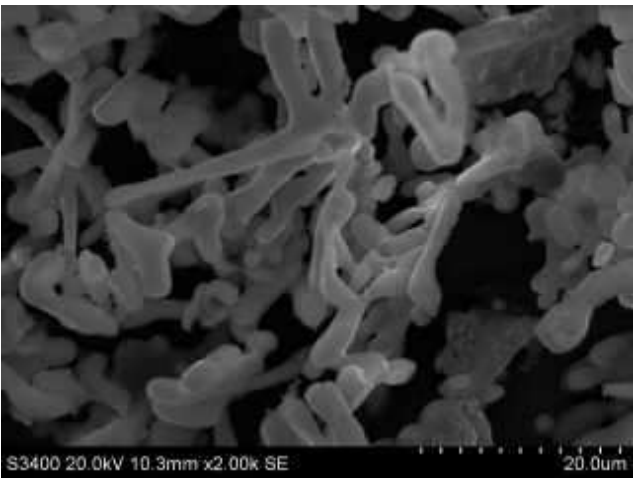

(a)

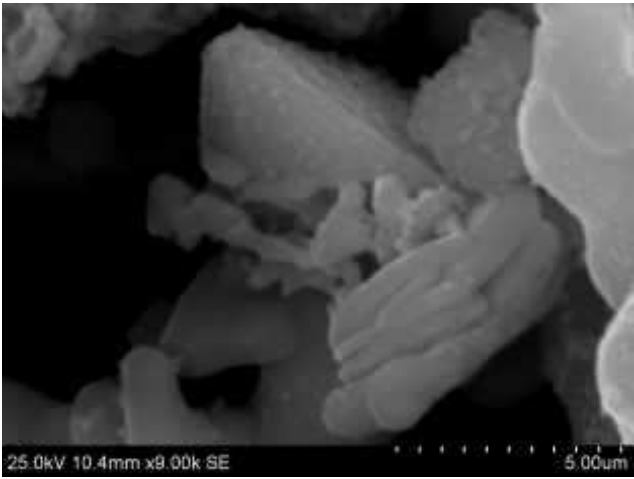

(c)
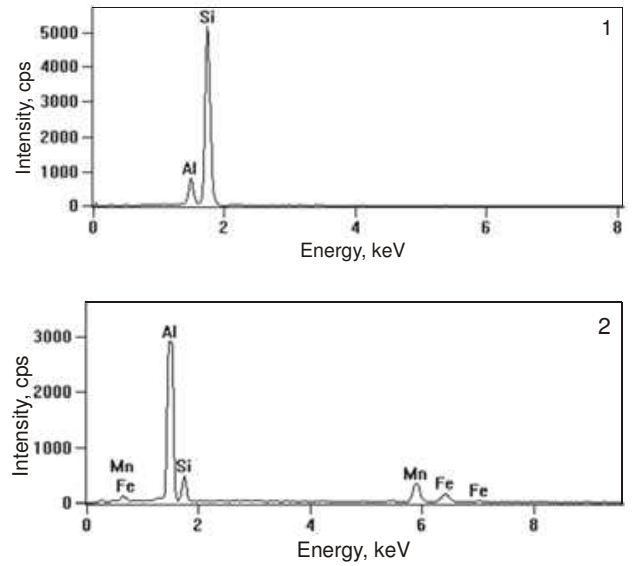

(e)

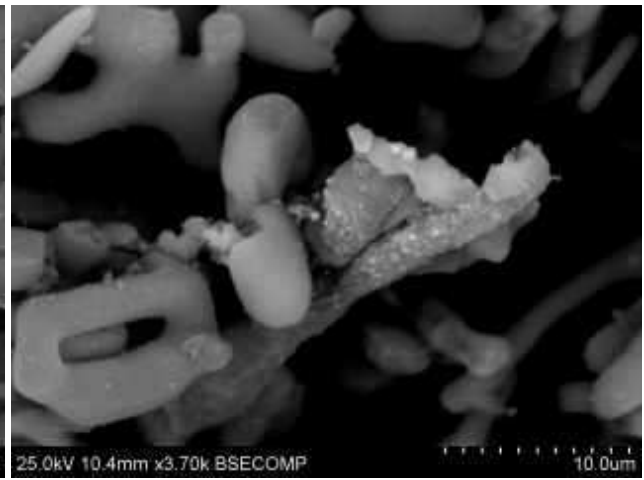

(b)

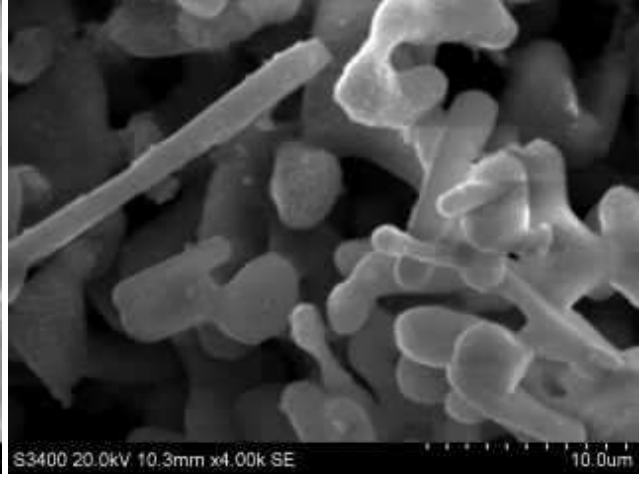

(d)
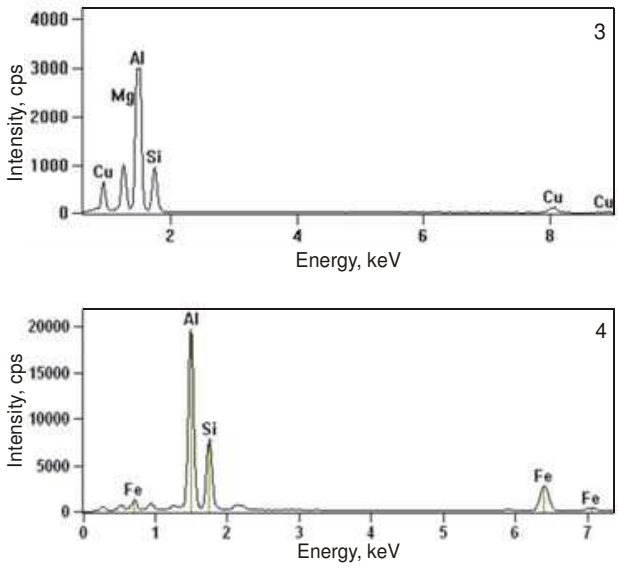

(f)

Fig. 11. SEM micrographs (a-d) of the particles extracted from the AlSi5Cu1Mg alloy and EDS spectra $(\mathrm{e}, \mathrm{f})$ 


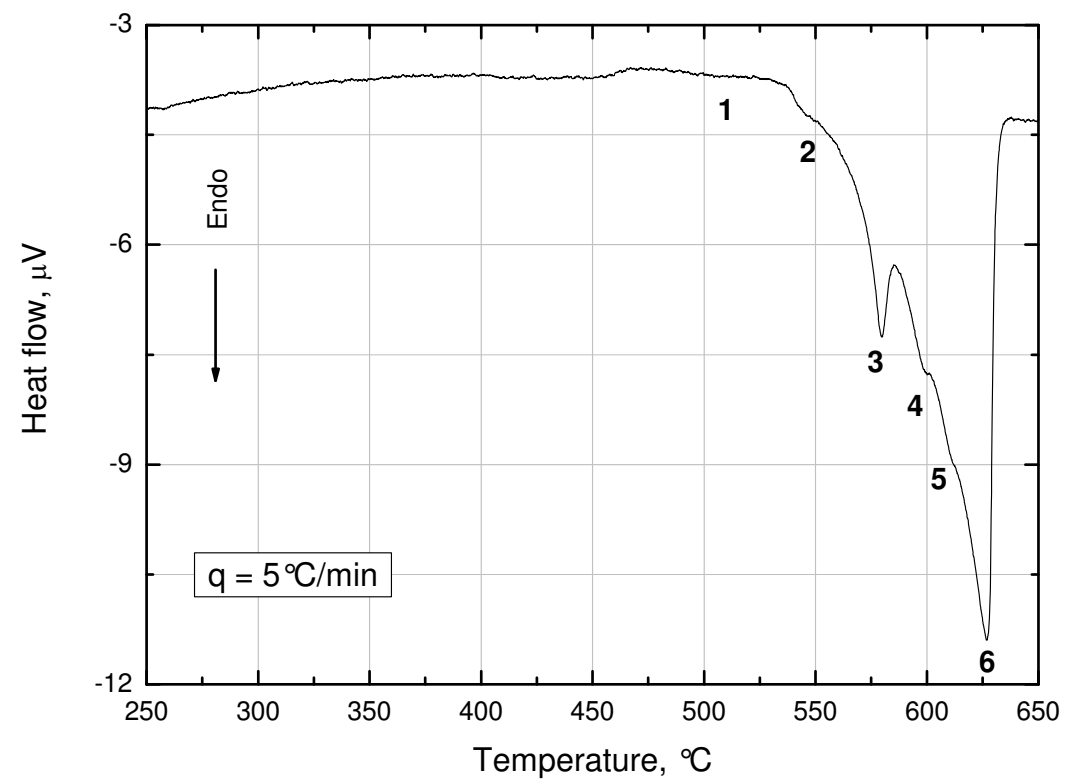

(a)

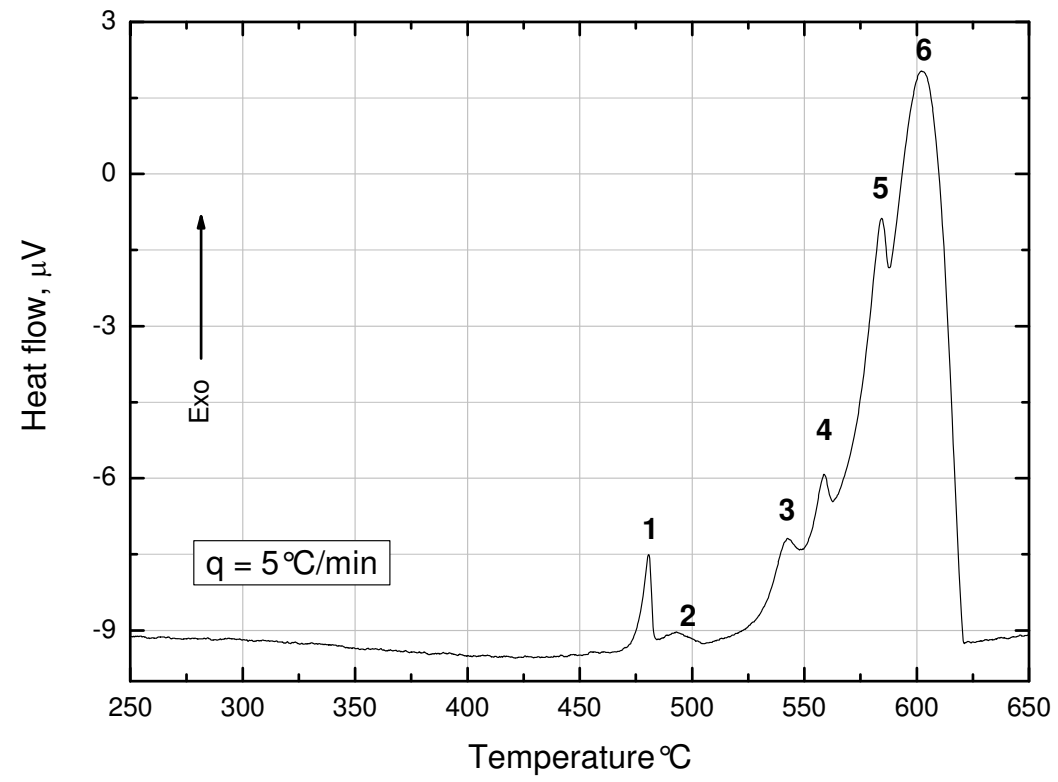

(b)

Fig. 12. DSC thermograms of as-cast specimens of AlCu4Ni2Mg2 alloy, obtained during a) heating and b) cooling at a rate of $5^{\circ} \mathrm{C} / \mathrm{min}$ 
The results of XRD investigation are shown in Fig. 8. X-ray diffraction analysis of AlSi1MgMn alloy confirmed metalograffic observation. Additionaly the presented above results were compared to the analysis of the particles extracted from the AlSi5Cu1Mg alloy using phenolic dissolution technique (Fig. 11). The EDS spectra revealed the presence of $\mathrm{Al}$, $\mathrm{Mg}, \mathrm{Mn}, \mathrm{Si}, \mathrm{Fe}$ and $\mathrm{Cu}$ - bearing particles in the extracted powder (Fig. 11). The EDS analysis results proof that analyzed particles extracted from the AlSi5Cu1Mg alloy were: $\mathrm{Si}$, AlMnFeSi, $\mathrm{Al}_{5} \mathrm{FeSi}, \mathrm{Al}_{5} \mathrm{Mg}_{8} \mathrm{Cu}_{2} \mathrm{Si}_{6}$ phases.

DSC curves obtained by heating (Fig. 12a) and cooling (Fig. 12b) of as-cast specimens of $\mathrm{AlCu}_{4} \mathrm{Ni}_{2} \mathrm{Mg}_{2}$ alloy are shown in Fig. 12. DSC curves demonstrate reactions which occurred during heating and solidification process of the alloy. The obtained results were similar to the peaks observed during cooling of the samples of AlSi5Cu1Mg alloy - the recorded peaks were shifted to the lower values (Fig. 12b).

The solidification sequence of this alloy can be quite complex and dependent upon the cooling rate (Fig. 12). Possible reactions which occurred during solidification of $\mathrm{AlCu} 4 \mathrm{Ni} 2 \mathrm{Mg} 2$ alloy are presented in Tab. 5. Aluminum reach $(\alpha-\mathrm{Al})$ dendrites are formed at the beginning of solidification process. Additional alloying elements into the alloys $(\mathrm{Ni}, \mathrm{Cu}, \mathrm{Mg})$ as well as impurities (eg. Fe) change the solidification path and reaction products. Therefore, as-cast microstructure of the tested alloy exhibit the appearance of mixture of intermetallic phases (Fig. 13a). The solidification reactions (the exact value of temperature) obtained during DSC investigation presented in Tab. 5 .

\begin{tabular}{|l|l|}
\hline Possible reactions & Temperature, ${ }^{\circ} \mathrm{C}$ \\
\hline $\mathrm{L} \rightarrow(\mathrm{Al})+\mathrm{Al}_{6} \mathrm{Fe}$ & 612 \\
\hline $\mathrm{L} \rightarrow(\mathrm{Al})+\mathrm{Al}_{4} \mathrm{CuMg}$ & 584 \\
\hline $\mathrm{L} \rightarrow(\mathrm{Al})+\mathrm{Al}_{2} \mathrm{Cu}+\mathrm{Al}_{2} \mathrm{CuMg}$ & 558 \\
\hline $\mathrm{L} \rightarrow(\mathrm{Al})+\mathrm{Al}_{2} \mathrm{Cu}+\mathrm{Al}_{7} \mathrm{Cu}_{4} \mathrm{Ni}$ & 542 \\
\hline $\mathrm{L} \rightarrow(\mathrm{Al})+\mathrm{Al}_{2} \mathrm{Cu}+\mathrm{Al}_{2} \mathrm{CuMg}+\mathrm{Al}_{3}(\mathrm{CuFeNi})_{2}$ & 493 \\
\hline Solidus & 480 \\
\hline
\end{tabular}

Table 5. Possible solidification reactions during nonequilibrium conditions in investigated $\mathrm{AlCu} 4 \mathrm{Ni} 2 \mathrm{Mg} 2$ alloy, at a heating rate $5^{\circ} \mathrm{C} / \mathrm{min}$

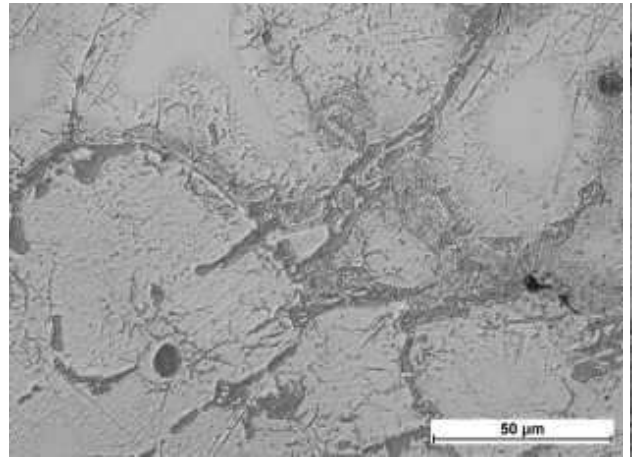

(a)

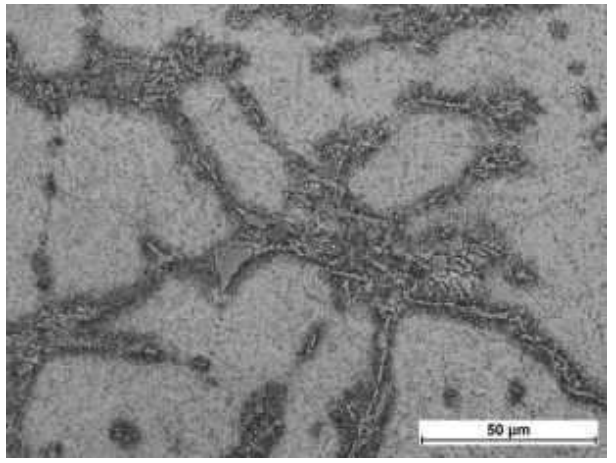

(b)

Fig. 13. The microstructure of AlCu4Ni2Mg2 alloy in as-cast state (a) and the T6 condition (b) 
The analyzed microstructure in as- cast state (Fig. 13a) contains of primary aluminium dendrites and substantial amount of different intermetallic phases constituents varied in shape, size and distribution. They are located at the grain boundaries of $\alpha-\mathrm{Al}$ and form dendrites network structure (Fig. 13a).

The analyzed microstructure of investigated AlCu4Ni2Mg2 alloy in T6 condition (Fig. 13b) consists different precipitates varied in shape, i.e.: fine sphere-like, complex rod-like and ellipse-like distributed within interdendritic areas of the $\alpha$-Al alloy. Large number of fine sphere-like strengthening phase are located in the boundary zone. However, small volume of this phase is also present homogenously throughout the sample (Fig. 13b). In order to identify the intermetallic phases in the examined alloy, series of distribution maps were performed for the elements line Mg-K, Al-K, Fe-K, Ni-K, Cu-K (Fig. 14). The maximum pixel spectrum clearly shows the presence of $\mathrm{Ni}$ and $\mathrm{Cu}$ in the scanned microstructure. In order to identify the presence of the elements in the observed phases, two regions of the mapped phase with high nickel and copper concentration were marked and their spectra evaluated.
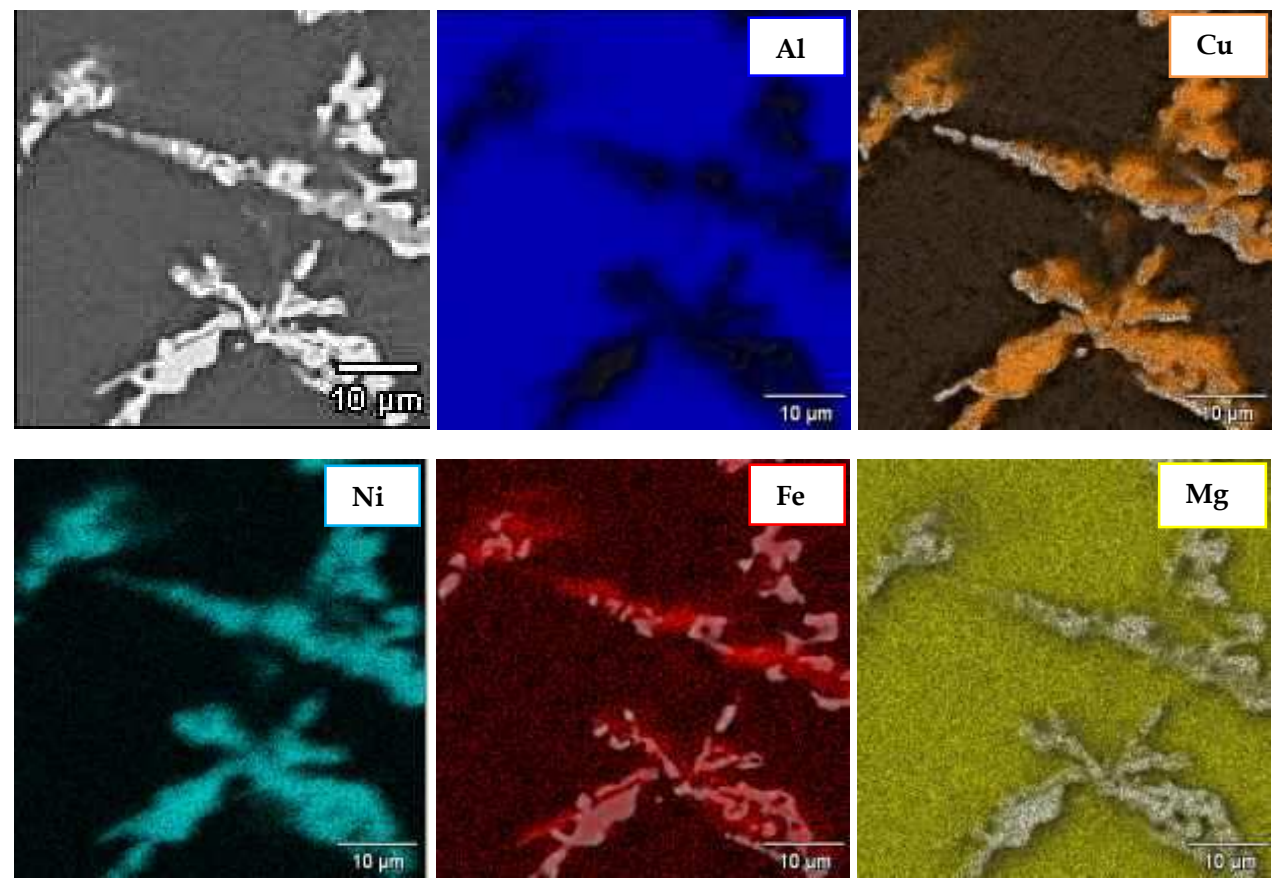

Fig. 14. SEM image of the $\mathrm{AlCu} 4 \mathrm{Ni} 2 \mathrm{Mg} 2$ alloy and corresponding elemental maps of: $\mathrm{Al}$, $\mathrm{Mg}, \mathrm{Fe}, \mathrm{Ni}$ and $\mathrm{Cu}$

As seen in the elemental maps in Fig. 14, the regions enriched in $\mathrm{Ni}$ and $\mathrm{Cu}$ correspond to the formation of type precipitates (complex rod-like) and ellipse-like precipitates observed in Fig. 13. Fig. 15 shows the scanning electron micrographs and EDS analysis of particles in the AlCu4Ni2Mg2 alloy.

The EDS analysis performed on the phases present in microstructure of the alloy revealed, that complex rod-like phase is the $\mathrm{Al}_{7} \mathrm{Cu}_{4} \mathrm{Ni}$ one, whereas the ellipse-like is $\mathrm{Al}_{3}(\mathrm{CuFeNi})_{2}$ (Fig. 15 and Tab. 6) 

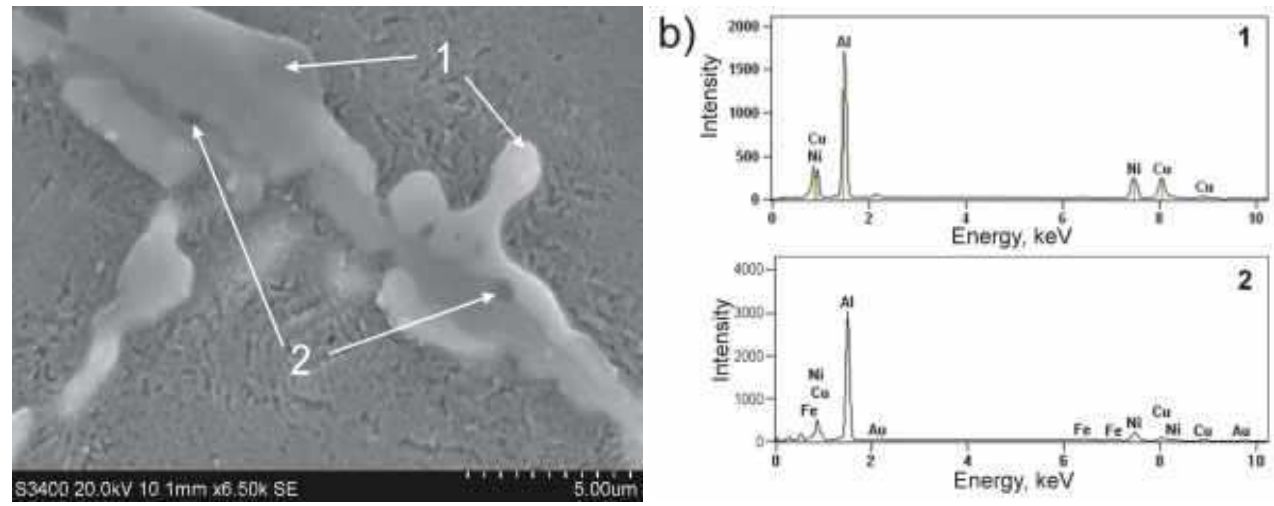

Fig. 15. a) SEM micrographs of the AlCu4Ni2Mg2 alloy in the T6 condition; b) The corresponding EDS-spectra acquired in positions indicated by the number 1 and 2

\begin{tabular}{|c|c|c|c|c|c|}
\hline \multirow{2}{*}{$\begin{array}{c}\text { No. of } \\
\text { analyzed } \\
\text { particles }\end{array}$} & \multirow{2}{*}{$\begin{array}{l}\text { Suggested } \\
\text { type of } \\
\text { phases }\end{array}$} & \multicolumn{3}{|c|}{$\begin{array}{l}\text { Chemical composition of determined } \\
\text { intermetallic phases, (\%at) }\end{array}$} & \multirow[t]{2}{*}{ Reference } \\
\hline & & $\mathbf{N i}$ & $\mathrm{Cu}$ & $\mathrm{Fe}$ & \\
\hline 20 & $\mathrm{Al}_{7} \mathrm{Cu}_{4} \mathrm{Ni}$ & $\begin{array}{c}11.8 \div 22.2 \\
18.08 \\
14.2 \div 22.6\end{array}$ & $\begin{array}{c}38.7 \div 50.7 \\
34.33 \\
29.7 \div 45.2\end{array}$ & & $\begin{array}{l}\text { Belov, } 2005 \\
\text { Chen, } 2010 \\
\text { This work }\end{array}$ \\
\hline 25 & $\mathrm{Al}_{3}(\mathrm{CuFeNi})_{2}$ & $\begin{array}{c}18 \div 22 \\
17.1 \div 20.5\end{array}$ & $\begin{array}{c}9 \div 15 \\
10.5 \div 19.3\end{array}$ & $\begin{array}{c}8 \div 10 \\
7.2 \div 9.5\end{array}$ & $\begin{array}{l}\text { Belov, } 2002 \\
\text { This work }\end{array}$ \\
\hline 12 & $\mathrm{Al}_{2} \mathrm{Cu}$ & & $\begin{array}{c}52.5 \\
47.7 \div 51.9\end{array}$ & & $\begin{array}{l}\text { Belov, } 2005 \\
\text { This work }\end{array}$ \\
\hline
\end{tabular}

Table 6. The chemical composition and volume fraction of the intermetallic phases in the AlCu4Ni2Mg2 alloy
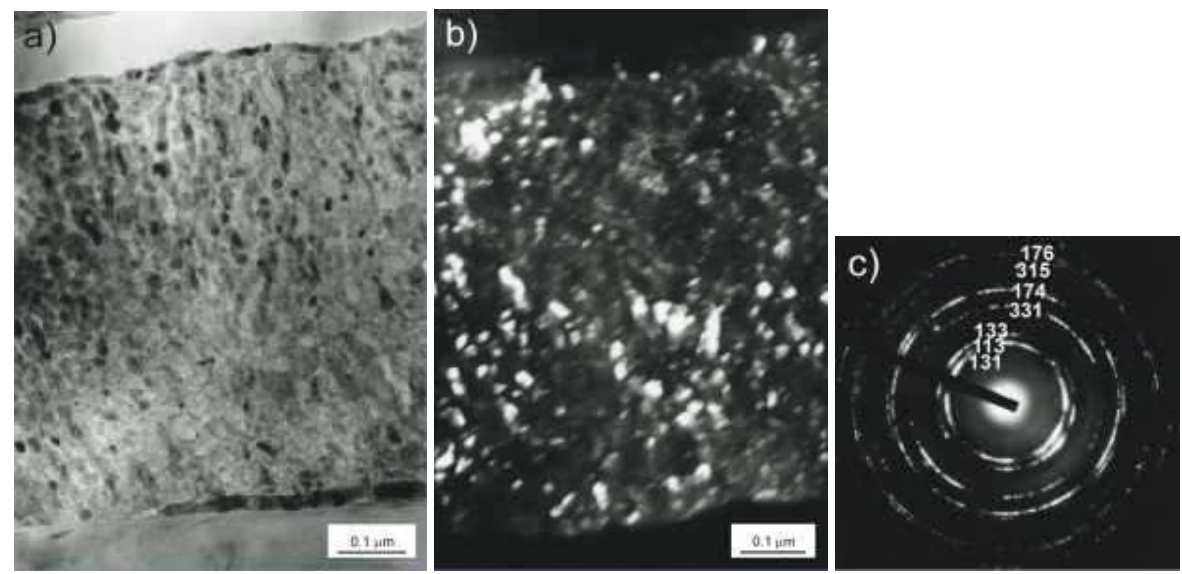

Fig. 16. TEM micrograph of $\mathrm{AlCu} 4 \mathrm{Ni} 2 \mathrm{Mg} 2$ alloy in $\mathrm{T} 6$ conditions showing the precipitate of the $\mathrm{S}-\mathrm{Al}_{2} \mathrm{CuMg}$ phase $(\mathrm{a}, \mathrm{b})$, and corresponding electron diffraction pattern (c) 
The microstructure of the examined alloy AlCu4Ni2Mg2 in $\mathrm{T} 6$ state consists of the primary precipitates of intermetallic phases combined with the highly dispersed particles of hardening phases. The TEM micrographs and the selected area electron diffraction patterns analysis proved that the dispersed precipitates shown in Fig. 13b are the intermetallic phases $\mathrm{S}-\mathrm{Al}_{2} \mathrm{CuMg}$ (Fig. 16) and $\mathrm{Al}_{6} \mathrm{Fe}$ (Fig. 17) besides the precipitates of hardening phase $\theta^{\prime}-\mathrm{Al}_{2} \mathrm{Cu}$ were present in $\mathrm{AlCu} 4 \mathrm{Ni} 2 \mathrm{Mg} 2$ alloy (Fig. 18). The approximate size of the $\mathrm{S}$ phase was $0,5 \mu \mathrm{m}$.
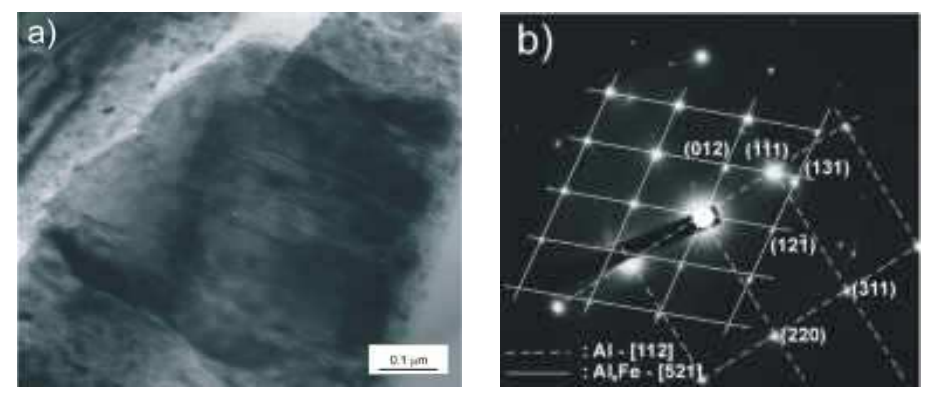

Fig. 17. TEM micrograph of $\mathrm{AlCu} 4 \mathrm{Ni} 2 \mathrm{Mg}$ alloy in $\mathrm{T} 6$ condition showing the precipitate of the $\mathrm{Al}_{6} \mathrm{Fe}$ phase (a), and corresponding electron diffraction pattern (b)
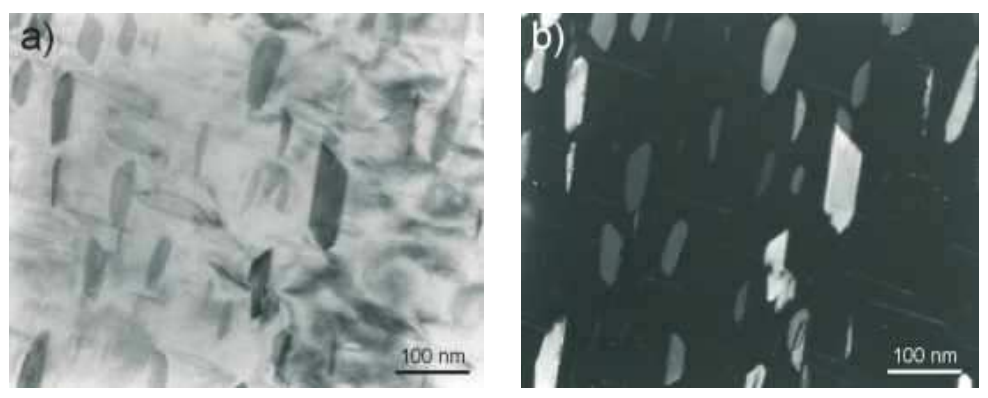

Fig. 18. TEM micrograph of AlCu4Ni2Mg alloy in T6 condition showing the precipitates of hardening phase $\theta^{\prime}-\mathrm{Al}_{2} \mathrm{Cu}$, bright field (a) and dark field (b)

The results of the SEM/EDS analysis of the particles extracted with boiling phenol from $\mathrm{AlCu} 4 \mathrm{Ni} 2 \mathrm{Mg} 2$ alloy (Fig. 19) were compared with X-ray diffraction pattern (Fig. 20). The observed peaks confirmed SEM and TEM results. The majority of the peaks were from $\mathrm{Al}_{7} \mathrm{Cu}_{4} \mathrm{Ni}, \mathrm{Al}_{6} \mathrm{Fe}, \mathrm{S}-\mathrm{Al}_{2} \mathrm{CuMg}$, and $\mathrm{Al}_{3}(\mathrm{CuFeNi})_{2}$.

On the other hand, it is nearly impossible to make unambiguous identification of the all intermetallics present in an aluminium alloy which are rather complex, even applying all well-known experimental techniques. X-ray diffraction analysis is one of the most powerful and appropriate technique giving the possibility to determine most of verified intermetallics based on their crystallographic parameters. Our analysis shows that the difficulties of having reliable results of all the possible existing phases in a microstructure of the alloy is related to the procedure of phase isolation. The residue is separated by centrifuging and since some of the particles are very fine and available sieves are having too big outlet holes there is no chance prevents them from being flowing out from a solution. 


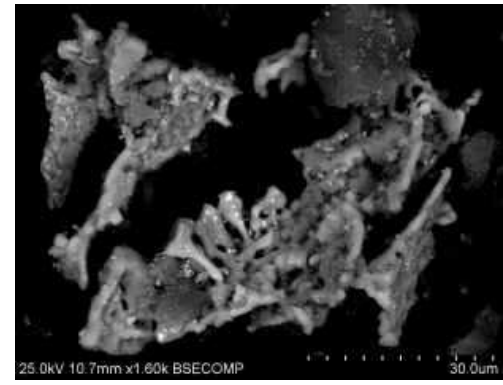

(a)

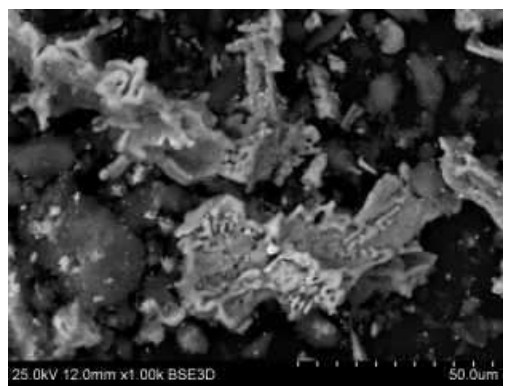

(c)

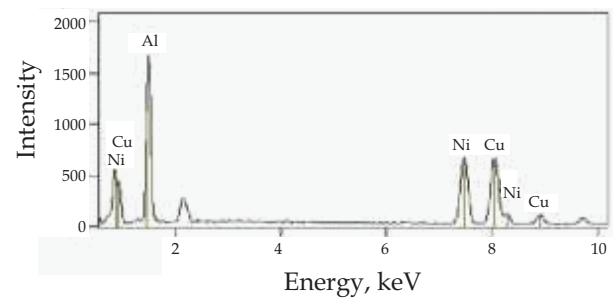

(e)

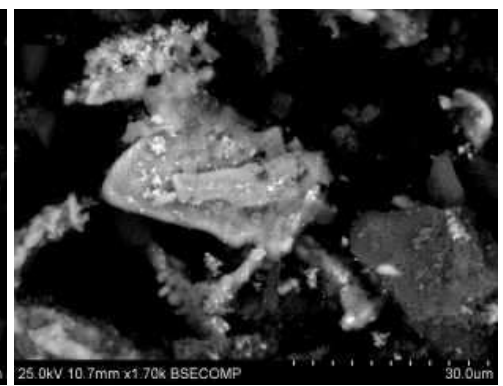

(b)

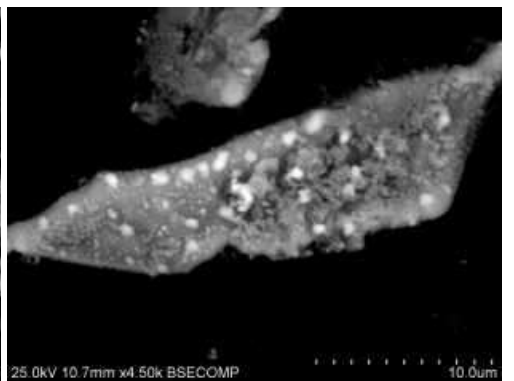

(d)

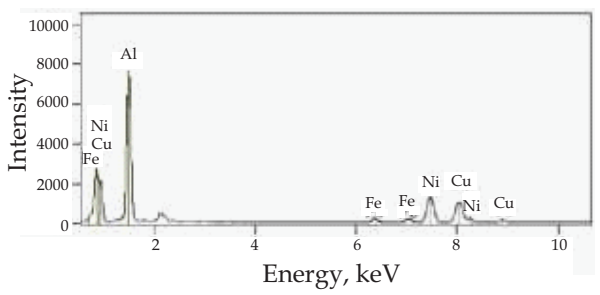

(f)

Fig. 19. SEM micrographs of the particles $\mathrm{Al}_{7} \mathrm{Cu}_{4} \mathrm{Ni}(\mathrm{a}, \mathrm{c})$ and $\mathrm{Al}_{3}(\mathrm{CuFeNi})_{2}(\mathrm{~b}, \mathrm{~d})$ extracted from the $\mathrm{AlCu} 4 \mathrm{Ni} 2 \mathrm{Mg} 2$ alloy along with EDS spectra $(\mathrm{e}, \mathrm{f})$

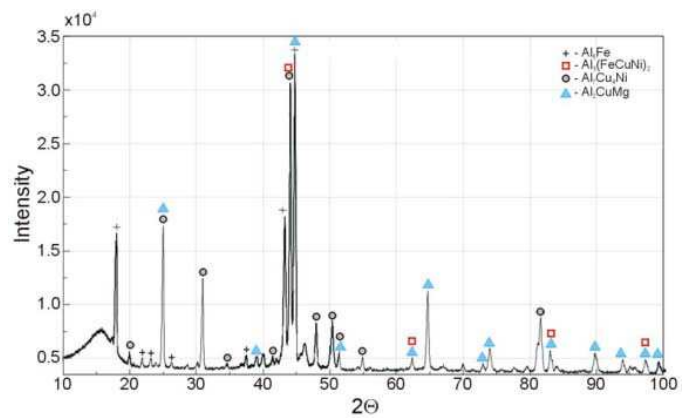

Fig. 20. The X-ray diffraction from the particles extracted from $\mathrm{AlCu} 4 \mathrm{Ni} 2 \mathrm{Mg} 2$ alloy 


\section{Conclusion}

Currently, efforts are being directed towards the development of analytical techniques which rapidly achieve an accurate determination of phase components in an alloy. According to the obtained results, the applicability of the proposed methods provides a practical alternative to other techniques. The phenol extraction procedure was also successfully applied to the examined aluminium alloys. The main advantages of dissolution techniques are its reliability - when used properly you will always get pure residue - and its low price. The major disadvantageous of phenol extraction method are the possible contamination of the residue and the time needed.

The examined alloys $\mathrm{AlSi} 5 \mathrm{Cu} 1 \mathrm{Mg}$ and $\mathrm{AlCu} 4 \mathrm{Ni} 2 \mathrm{Mg} 2$ possessed a complex microstructure. By using various instruments and techniques (LM, SEM-EDS, TEM and XRD) a wide range of intermetallics phases were identified. The microstructure of investigated AlSi5Cu1Mg alloy included: $\beta-\mathrm{Al}_{5} \mathrm{FeSi}, \alpha-\mathrm{Al}_{12}(\mathrm{FeMn})_{3} \mathrm{Si}, \mathrm{Al}_{2} \mathrm{Cu}, \mathrm{Q}-\mathrm{Al}_{5} \mathrm{Cu}_{2} \mathrm{Mg}_{8} \mathrm{Si}_{6}, \mathrm{Si}$ and $\mathrm{Mg}_{2} \mathrm{Si}$ phases. The microstructure of $\mathrm{AlCu} 4 \mathrm{Ni} 2 \mathrm{Mg} 2$ alloy included five phases, namely: $\mathrm{Al}_{7} \mathrm{Cu}_{4} \mathrm{Ni}, \theta^{\prime}-\mathrm{Al}_{2} \mathrm{Cu}$, $\mathrm{Al}_{6} \mathrm{Fe}, \mathrm{S}-\mathrm{Al}_{2} \mathrm{CuMg}$, and $\mathrm{Al}_{3}(\mathrm{CuFeNi})_{2}$. A size and distribution of these various dispersoids depend on the time and temperature of the homogenization and/or annealing processes. Fine intermetallic particles $(<l \mu \mathrm{m})$ are formed during artificial aging of heat-treatable alloys and are more uniformly distributed than constituent particles or dispersoids. Dimensions, shape and distribution of these particles may have important effects on the ductility of alloys and more needs to be known regarding their formation, structure and composition. For example, the coarse particles can influence the recrystallization, fracture, surface, and corrosion behavior, while the dispersoids control grain size and provide stability to the metallurgical structure. The dispersoids can also affect the fracture performance and may limit strain localization during deformation. The formation of particles drains solute from the matrix and, consequently, changes the strength properties of the material. This is specially relevant in the heat-treatable alloys, where depletion in $\mathrm{Cu}, \mathrm{Mg}$, and $\mathrm{Si}$ can significantly change the metastable precipitation processes and age hardenability of a material. Therefore, particle characterization is essential not only for choosing the best processing routes, but also for designing optimized alloy composition. Thus, particle characterization is important not only to decide what sort of processing courses should be applied, but also for designing optimized chemical composition of a material. A variety of microscopic techniques are well appropriate to characterize intermetallics but only from a small section of an analyzed sample. From commercial point of view it is extremely advantageous to provide use quick, reliable and economical examination technique capable of providing data of particles from different locations of a full scale-sized ingot. One of these methods is dissolving the matrix of an aluminium alloy chemically or electrochemically.

\section{Acknowledgment}

This work was carried out with the financial support of the Ministry of Science and Higher Education under grant No. N N507 247940

\section{References}

Bäckerud, L. \& Chai, G. (1992). Solidification Characteristics of Aluminum Alloys 3, American Foundry Society, Des Plaines, Illinois 
Belov, N.A., Aksenov, A.A. \& Eskin, D.G. (2002). Iron in aluminium alloys, Taylor \& Francis Inc, New York, ISBN 0-415-27352-8

Belov, N.A., Eskin, D.G. \& Avxentieva, N.N. (2005). Constituent phase diagrams of the Al$\mathrm{Cu}-\mathrm{Fe}-\mathrm{Mg}-\mathrm{Ni}-\mathrm{Si}$ system and their application to the analysis of aluminium piston alloys, Acta Materialia, No. 53 pp.4709-4722

Cabibbo, M., Spigarelli, S. \& Evangelista, E. (2003). A TEM investigation on the effect of semisolid forming on precipitation processes in an Al-Mg-Si alloy, Materials Characerisation, No. 49, pp. 193-202

Chen, C.L. \& Thomson, R.C. (2010). Study of thermal expansion of intermetallics in multicomponent Al-Si alloys by high temperature X-ray diffraction, Intermetallics, No. 18, pp 1750-1757

Christian, J.W. (1995). The theory of transformations in metals and alloys. Pergamon Press, Oxford, Anglia

Dobrzański, L.A., Maniara, R. \& Sokolooki, J.H. (2007). Microstructure and mechanical properties of AC AlSi9CuX alloys, Journal of Achievements in Materials and Manufacturing Engineering, Vol. 24, No.2, pp. 51-54

Garcia-Hinojosa, J.A., González, C.R., González, G.M. \& Houbaert, Y. (2003). Structure and properties of Al-7Si-Ni and Al-7Si-Cu cast alloys nonmodified and modified with Sr, Journal of Materials Processing Technology, No. 143-144, pp. 306-310

Gupta, A.K., Lloyd, D.J. \& Court S.A. (2001). Precipitation hardening in Al-Mg-Si alloys with and without excess Si. Materials Science and Engineering A, No. 316, pp. 11-17

Gustafsson, G., Thorvaldsson, T. \& Dunlop, G.L. (1986). The influence of Fe and Cr on the microstructure of cast Al-Mg-Si alloys, Metallurgical and Materials Transactions. A, No. 17A, pp. 45-52

Griger, A. \& Stefaniay V. (1996). Equilibrium and non-equilibrium intermetallic phases in Al-Fe and Al-Fe-Si alloys, Journal of Materials Science, No. 31, pp. 6645-6652

Hatch, J.E (1984). Aluminium. Properties and Physical Metallurgy. Ed.., ASM Metals Park, Ohio, ISBN 0-87170-176-6

Ji, Y. Guo, F. \& Pan, Y. (2008). Microstructural characteristics and paint-bake response of Al-Mg-Si-Cu alloy, Transactions of Nonferrous Metals Society of China, No.18, pp. 126129

Karabay, S., Yilmaz, M. \& Zeren, M. (2004). Investigation of extrusion ratio effect on mechanical behaviour of extruded alloy AA-6101 from the billets homogenisedrapid quenched and as-cast conditions. Journal of Materials Processing Technology, No. 160 , pp. $138-147$

King, F. (1987). Aluminium and its alloys. John Willey and Sons, New York, Chichester, Brisbane, Toronto

Kuijpers, N.C.W., Kool, W.H. \& van der Zwaag, S. (2002). DSC study on Mg-Si phases in as cast AA6xxx. Mater. Sci. Forum, No. 396-402, pp. 675-680

Li, Z., Samuel, A.M., Samuel, F.H., Ravindran, C., Valtierra, S. \& Doty, H.W. (2004). Parameters controlling the performance of AA319-type alloys Part I. Tensile properties, Materials Science and Engineering, No. 367, pp. 96-110

Liu, Y.L. Kang, S.B. \&. Kim, H.W. (1999). The complex microstructures in as-cast Al-Mg-Si alloy, Materials Letters, No. 41, pp. 267-272

Lodgaard, L. \& Ryum, N. (2000). Precipitation of dispersoids containing Mn and/or Cr in Al-Mg-Si alloys, Materials Since and Engineering A, No.283, pp. 144-152 
Mondolfo, L.F, (1976). Aluminium Alloys: Structure and Properties. London-Boston, Butterworths

Mrówka-Nowotnik, G. \& Sieniawski, J. (2005). Influence of heat treatment on the micrustructure and mechanical properties of 6005 and 6082 aluminium alloys, Journal of Materials Processing Technology, Vol. 162-163, No. 20, pp. 367-372

Mrówka-Nowotnik, G., Sieniawski, J. \& Wierzbińska, M. (2007). Analysis of intermetallic particles in AlSi1MgMn aluminium alloys, Journal of Achievements in Materials and Manufacturing Engineering, No. 20 pp. 155-158.

Mrówka-Nowotnik, G., Sieniawski, J. \& Wierzbińska, M. (2007). Intermetallic phase particles in 6082 aluminium alloy, Archives of Materials Science and Engineering, No. 282, pp. $69-76$

Polmear, I.J. (1995). Light alloys. Metallurgy of light metals. Arnold, London-New YorkSydney-Auckland, ISBN 0-7506-6371-5

Sato, K. \& Izumi I. (1985). Application of the technique for isolating and analysis intermetallic compounds to commercial aluminium alloys, Journal of Japan Institute of Light Metals, No. 35, pp. 647-649

Warmuzek, M., Sieniawski, J., Wicher, K. \& Mrówka-Nowotnik, G. (2003). Analiza procesu powstawania składników fazowych stopu AlFeMnSi w warunakch zmiennej zawartości metali przejściowych Fe i Mn. Inżynieria Materiałowa, No. 137, pp. 821824

Warmuzek, M., Mrówka, G. \& Sieniawski, J. (2004). Influence of the heat treatment on the precipitation of the intermetallic phasesin commercial AlMn1FeSi alloy. Journal of Materials Processing Technology, 157-158, No. 20, (December 2004) pp. 624-632, ISSN 0924-0136

Warmuzek, M., Rabczak, K. \& Sieniawski, J. (2005). The course of the peritectic transformation in the Al-rich Al-Fe-Mn-Si alloys, Journal of Materials Processing Technology, No. 162-163, pp. 422-428

Warmuzek, M., Sieniawski, J., Wicher, K. \& Mrówka-Nowotnik, G. (2006). The study of distribution of the transition metals and Si during primary precipitation of the intermetallic phases in Al-Mn-Si alloys, Journal of Materials Processing Technology Vol. 1-3, No. 175, pp. 421-426

Wierzbińska, M. \& Mrówka-Nowotnik, G. (2008). Identification of phase composition of AlSi5Cu2Mg aluminium alloy in T6 condition, Archives of Materials Science and Engineering, Vol. 30, No. 2, pp. 85-88

Zajac, B., Bengtsson, Ch. \& Jönsson, (2002). Influence of cooling after homogenization and reheating to extrusion on extrudability and final properties of AA 6063 and AA 6082 alloys, Materials Science Forum, No. 396-402, pp. 675-680

Zhen, L. \& Kang, S.B. (1998). DSC analyses of the precipitation behavior of two Al-Mg-Si alloys naturally aged for different times, Materials Letters. No. 37, pp. 349-353 


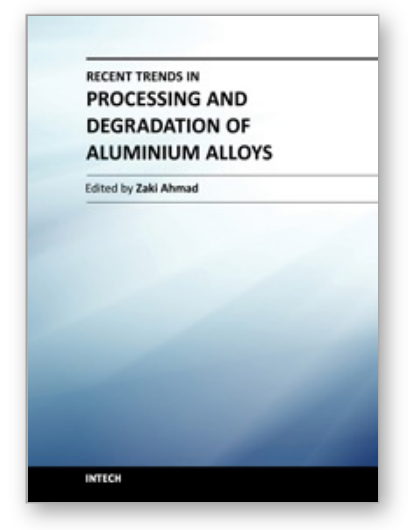

\section{Recent Trends in Processing and Degradation of Aluminium Alloys \\ Edited by Prof. Zaki Ahmad}

ISBN 978-953-307-734-5

Hard cover, 516 pages

Publisher InTech

Published online 21, November, 2011

Published in print edition November, 2011

In the recent decade a quantum leap has been made in production of aluminum alloys and new techniques of casting, forming, welding and surface modification have been evolved to improve the structural integrity of aluminum alloys. This book covers the essential need for the industrial and academic communities for update information. It would also be useful for entrepreneurs technocrats and all those interested in the production and the application of aluminum alloys and strategic structures. It would also help the instructors at senior and graduate level to support their text.

\section{How to reference}

In order to correctly reference this scholarly work, feel free to copy and paste the following:

Grazyna Mrówka-Nowotnik (2011). Intermetallic Phases Examination in Cast AlSi5Cu1Mg and AICu4Ni2Mg2 Aluminium Alloys in As-Cast and T6 Condition, Recent Trends in Processing and Degradation of Aluminium Alloys, Prof. Zaki Ahmad (Ed.), ISBN: 978-953-307-734-5, InTech, Available from:

http://www.intechopen.com/books/recent-trends-in-processing-and-degradation-of-aluminium-

alloys/intermetallic-phases-examination-in-cast-alsi5cu1 mg-and-alcu4ni2mg2-aluminium-alloys-in-as-cast-and-

\section{INTECH}

open science | open minds

\section{InTech Europe}

University Campus STeP Ri

Slavka Krautzeka 83/A

51000 Rijeka, Croatia

Phone: +385 (51) 770447

Fax: +385 (51) 686166

www.intechopen.com

\section{InTech China}

Unit 405, Office Block, Hotel Equatorial Shanghai

No.65, Yan An Road (West), Shanghai, 200040, China

中国上海市延安西路65号上海国际贵都大饭店办公楼405单元

Phone: +86-21-62489820

Fax: +86-21-62489821 
(C) 2011 The Author(s). Licensee IntechOpen. This is an open access article distributed under the terms of the Creative Commons Attribution 3.0 License, which permits unrestricted use, distribution, and reproduction in any medium, provided the original work is properly cited. 